\title{
Strategic priorities and competitiveness of businesses operating in different entrepreneurial ecosystems: A benefit of the doubt (BOD) analysis
}

\author{
Esteban Lafuente \\ Department of Management, UPC Barcelona Tech \\ E-mail: esteban.lafuente@upc.edu \\ Suyen Alonso-Ubieta \\ Universidad Nacional, Costa Rica \\ E-mail: salonso@una.ac.cr \\ Juan Carlos Leiva \\ School of Business Campus Cartago, Costa Rica Institute of Technology (ITCR) \\ E-mail: jleiva@itcr.ac.cr \\ Ronald Mora-Esquivel \\ School of Business Campus Cartago, Costa Rica Institute of Technology (ITCR) \\ E-mail: $\underline{\text { rmora@itcr.ac.cr }}$
}

\begin{abstract}
:
This study evaluates the relationship between the entrepreneurial ecosystem and business competitiveness. The study uses a sample of 348 manufacturing and knowledge-intensive business service firms operating in four countries with different entrepreneurial ecosystem (France, Spain, Costa Rica, and Hungary) for 2019. Firm competitiveness is computed via the 'benefit-of-thedoubt' (BOD) method, and a multilevel model is employed to assess the connection between the entrepreneurial ecosystem and firm competitiveness. The results of the multilevel model indicate that the entrepreneurial ecosystem is related to firm competitiveness, while the BOD results suggest that firms operating in settings with a more consolidated entrepreneurial ecosystem are better able to realize the outcomes of strategic choices linked to the exploitation of key resources and capabilities. Country-specific results suggest that 'human capital' is the most relevant competitive pillar prioritized by all sampled businesses. The proposed analysis contributes to the development of the entrepreneurial ecosystem frame by offering insights on how the properties of the entrepreneurial ecosystem (i.e., interactions among individuals, organizations and institutions) can produce economically meaningful effects on business performance.
\end{abstract}

Keywords: Entrepreneurial ecosystem, business competitiveness, benefit of the doubt model, KIBS firms, manufacturing firms, Costa Rica, Spain

\section{WORKING PAPER VERSION. PLEASE CITE AS:}

Lafuente, E., Alonso, S., Leiva, J.C., Mora-Esquivel, R. (2021). Strategic priorities and competitiveness of businesses operating in different entrepreneurial ecosystems: A benefit of the doubt (BOD) analysis. International Journal of Entrepreneurial Behavior \& Research, in press, doi: 10.1108/IJEBR-06-2020-0425 


\section{Strategic priorities and competitiveness of businesses operating in different entrepreneurial ecosystems: A benefit of the doubt (BOD) analysis}

"At a fundamental level, ecosystems provide new ways of managing the trade-off between flexibility and commitment. In general, companies can either make flexible decisions, as in launching a pilot project, or they can commit themselves to a particular strategic path, which is often necessary to reach efficient scale and secure competitive advantage."

—Fuller, J., Jacobides, M. and Reeves, M. (February 25, 2019), MIT Sloan Management Review ${ }^{1}$

\section{Introduction}

During the last decade, academics and policy makers have witnessed a radical shift in the way to study country-level entrepreneurship, which has evolved from a view dominated by the use of ratio variables (e.g., rate of new firms and the GEM's entrepreneurial activity variables) to a more holistic approach in which the entrepreneurial ecosystem (EE) and its constituents are decisive to conceptualize and analyze country-level entrepreneurship and its economic effects (Acs et al., 2014; Acs et al., 2017, Isenberg 2010; Lafuente, Acs et al., 2020; Lux et al., 2020; Spigel, 2017).

Studies in this tradition-mostly inspired by, among others, Moore (1993) and van de Ven (1993), and further developed by Isenberg (2010)—emphasize the multidimensionality of EEs, while acknowledging the role of the interdependence between various territorial elements (e.g., social, economic, and institutional) in explaining the evolution of EEs (Acs et al., 2014; Cavallo et al., 2019; Cao and Shi, 2020; Lux et al., 2020). Building on the EE frame, recent work points out to a number of factors promoting knowledge generation and exploitation as well as new firm formation, which are of great relevance given their potentially positive economic effects (e.g., Horváth and Rabetino, 2019; Lafuente et al., 2017).

Relative to canonical approaches that portray firm creation as an individual-led effort, the primary postulates of the EE frame are that business creation arises from social processes, and that the interaction between entrepreneurs and their environment is a potent factor explaining the creation and subsequent performance of new ventures (Isenberg, 2010). The EE literature has proposed a wide range of elements that characterize this linkage and explain how the connections between economic agents and contextual factors trigger entrepreneurship (Acs et al., 2014, Brown and Mawson, 2019; Lafuente, Acs et al., 2020; Lux et al., 2020; Spigel, 2017, Stam, 2015).

The stock of knowledge dealing with EEs has grown rapidly during the last decade; however, as any novel field the EE frame is still evolving. EEs are not checklists, and recent work highlights

\footnotetext{
${ }^{1}$ https://sloanreview.mit.edu/article/the-myths-and-realities-of-business-ecosystems
} 
at least three research priorities: (1) the development of a solid theory that consolidates the EE as a research field (Acs et al., 2014; Brown and Mason, 2017; Lux et al., 2020; Spigel, 2017; Stam, 2015); (2) the need to reach consensus on the EE's constituents in order to better explain the link between EEs and territorial outcomes (Godley et al., 2021; Horváth and Rabetino, 2019; Wyrwich, 2019) and; (3) studying the role of EE on firm performance using methodologies compatible with the multidimensionality of EEs (Lafuente, Acs et al., 2020; Stam and van de Ven, 2021).

The characteristics of the national EE may influence firm competitiveness (Wurth et al., 2021). Therefore, in strict connection with the third point highlighted above, the analysis of the relationship between EEs and business competitiveness is the core of this study. Underlying the EE framework is the presumption that EEs act like an institutional umbrella that contributes to efficiently channel resources to the economy and, subsequently, to enhance firm performance (Acs et al., 2014; Brown and Mawson, 2019; Lafuente, Acs et al., 2020; Spigel 2017). In this discussion, it has been argued that the efficient mobilization of resources characterizes territories with a healthy EE (Acs et al. 2014). In the context of the local production function and its technological restrictions, this market process facilitates the access and exploitation of critical resources which would help new and incumbent businesses to develop relevant competencies that, in turn, will likely contribute to increase output levels and enhance business competitiveness. This process connecting the characteristics of the national EE and business outcomes has been associated with the economic effects of Kirznerian entrepreneurship (see, e.g., Lafuente, Acs et al. (2020) for a comprehensive discussion on the role of Kirznerian and Schumpeterian entrepreneurship on the economy).

Following this logic, a relevant question rising is whether business competitiveness is affected by the EE. Moreover, do differences in the EE contribute to explain discrepancies in firms' competitiveness-enhancing strategies, in terms of the exploitation of businesses' resources and capabilities? To answer these questions empirically, the objective of this study is to evaluate the relationship between the EE and firm competitiveness in different contexts (i.e., France, Spain, Costa Rica and Hungary), while acknowledging that business competitiveness is a multifaceted construct resulting from strategic decisions-linked to the configuration of resources and capabilities - that can be molded by the characteristics of countries’ EE.

To step in this direction, the analysis uses a dataset built from two sources: data on business competitiveness for a sample of 348 manufacturing and knowledge-intensive business services (KIBS) firms was obtained from the Global Competitiveness Project databases (GCP: www.smegcp.org) (Lafuente, Leiva et al., 2020), while information on the countries' EE was collected from the Global Entrepreneurship and Development Institute (GEDI: www.thegedi.org) (Acs et al., 2014). 
A number of considerations should be made when analyzing firms operating in countries with different development levels. First, the structural differences that exist between the studied developed and developing countries-e.g., industrial specializations or access to different resources-overlap with the distinctive properties of the institutional setting (Acs et al., 2014). In this sense, it would be interesting to analyze if the competitiveness drivers-in terms of the exploitation of resources and capabilities_for firms operating in developing economies follow a different strategic path, relative to that observed for organizations located in developed countries. Besides the value of studying the similarities and/or disparities in competitiveness drivers between developed and developing countries, the use of a homogeneous competitiveness metric in different settings allows for generating comparable results that can unveil country-specific patterns that can be connected to the distinctive characteristics of the national EE.

Second, the proposed analysis of the role of the configuration of competitive pillars on competitiveness efficiency provides an opportunity to evaluate, in developed and developing countries, how different competencies contribute to competitiveness in two industries where the interactions between resources and capabilities are complex and heterogeneous.

Our focus on the competitive drivers of manufacturing and knowledge-intensive business service (KIBS) firms is in line with recent work emphasizing the importance of these industries for the consolidation of knowledge-based economies (e.g., Cusumano et al., 2015; Lafuente et al., 2019). Manufacturing firms are increasingly interacting with KIBS firms in order to introduce value-adding services into their operations, a process referred to as servitization (e.g., Crozet and Milet, 2017; Rabetino et al., 2018; Vendrell-Herrero et al., 2017). From a territorial perspective, recent work has shown how the presence of a strong KIBS sector helps manufacturers to alleviate operational weaknesses and internalize the introduction of advanced services, thus positively impacting territorial outcomes by improving the value-added of manufacturers' products (Jacobs et al., 2016; Lafuente et al., 2017 and 2019). Also, recent empirical evidence highlights the importance of various properties of the national EE in supporting the relationship between KIBS and manufacturers (e.g., Horváth and Rabetino, 2019; Wyrwich, 2019).

The results of the competitiveness analysis—computed by the non-parametric "benefit-of-thedoubt” (BOD) method (Cherchye et al., 2007)—corroborate that firms prioritize different resources and capabilities in order to enhance their competitiveness. The results of the multilevel model point to a connection between the countries' $\mathrm{EE}$ and the configuration of strategic resources and capabilities that, in turn, yield to superior competitiveness levels.

The relevance of this study stretches beyond computational exercises and has relevant implications within the EE field. First, from an organizational view, the proposed BOD model 
offers insights on how firms in different contexts pursuit competitiveness by orchestrating their resources and capabilities. This analysis may also provide nuanced guidance on how to support local firms by developing tailor-made policy actions that, at the same time, help to strengthen the national EE. Second, from a policy perspective, proposing a connection between the EE and business outcomes is a tempting objective, as it would suggest that social and economic mechanisms can produce, at different intensities, economically meaningful effects on firm competitiveness.

\section{Background theory}

\subsection{Entrepreneurial ecosystem}

The academic enthusiasm for developing and consolidating the EE as a research field has translated into a significant stock of scientific work that will likely continue to grow (see, e.g., Brown and Mason, 2017; Cavallo et al., 2019; Cao and Shi, 2020). Building on ecological metaphors originally proposed by Moore (1993) and popularized by Isenberg (2010), the entrepreneurial ecosystem construct has become a 'trendy topic' that has entered into the agenda of scholars and policy makers interested in identifying and upgrading the distinctive properties of EEs which are spatially and socially embedded (Acs et al., 2014; Acs et al. 2017; Brown and Mawson, 2019). As a result of the increased research efforts in the field, various scholars have explored and analyzed EEs seeking to provide a uniform or commonly accepted definition of this construct.

By examining the existing and most comprehensive definitions of EE-see, e.g., Acs et al. (2014, p. 479), Mason and Brown (2014, p. 4) or Spigel (2017, p. 50)—it is possible to identify common elements which emphasize the systemic nature of EEs as well as the crucial role played by multiple agents (institutions, organizations, and individuals). In this sense, the EE can be conceived as a dynamic, institutionally embedded umbrella that supports the interaction between different agents within the focal territory which, in turn, enhances resource mobilization and supports entrepreneurial action as well as the outcomes of new and incumbent ventures (Acs et al., 2014; Brown and Mawson, 2019; Lux et al., 2020; Stam, 2015; Van de Ven, 1993). Following this argument line, Spigel (2017) and Spigel and Harrison (2018) categorize the multiple EE constituents in cultural, social and material factors.

Concerning the EE constituents, cultural elements are the attitudes toward entrepreneurship, that is, the underlying beliefs about entrepreneurship among the population and the supportive entrepreneurship culture (Lux et al., 2020; Spigel, 2017; Stam, 2015). Evidence suggests that this cultural perspective influences regional entrepreneurship. For instance, positive cultural outlooks can normalize entrepreneurship risks and encourage firm creation, while negative outlooks produce 
the opposite (Fritsch and Storey, 2014). Besides, culture influences entrepreneurship by modeling acceptable entrepreneurial practices and norms (Lafuente and Vaillant, 2013).

Social elements refer to resources, such as talent, capital, networks, mentors, and role models. The social connotation is because these resources are composed of or acquired through regional social networks. For example, solid social networks are essential for entrepreneurship because they support knowledge diffusion processes (Audretsch et al., 2011). In the same line, social networks act as conduits for obtaining capital, mentorship, and talented workers (Lafuente et al., 2007).

Material elements comprise the institutions and organizations that support entrepreneurship that can be present in the region either physically (i.e., a university) or institutionally (i.e., governmental policy). These material elements help to provide new technologies that may create entrepreneurial opportunities (Lafuente, Acs et al., 2020), knowledge spillover effects (Acs et al., 2017), and specialized assistance (Patton and Kenney, 2005), among others.

Following this argument line, and in connection with the first research question ('does the EE affect business competitiveness?'), it is plausible to argue that territories with a consolidated EE will likely enhance the interconnection between entrepreneurs and their environment which, in turn, will contribute to productive entrepreneurship via resource mobilization processes (Acs et al., 2014). Furthermore, recent work on EEs emphasizes the relevance of resource mobilization processes, which results from specific strategies that improve resource exploitation and help new and incumbent businesses to realize their full competitive potential (e.g., Lafuente et al., 2017; Horváth and Rabetino, 2019; Wyrwich, 2019).

This logic and evidence lead us to formulate our first hypothesis:

H1: A positive relationship exists between the quality of the entrepreneurial ecosystemmeasured via the global entrepreneurship index (GEI)—and business competitiveness measured via a multidimensional composite indicator.

\subsection{The organizational effects of the entrepreneurial ecosystem}

The previous section typified the EE and attempted to depict that efficient resource mobilization is a relevant consequence of consolidated EEs. In line with the second research question of this study ('do differences in the national EE contribute to explain discrepancies in businesses' competitiveness-enhancing strategies?'), a critical aspect of this study is how to match EE properties to competitiveness-enhancing strategies by firms operating in different contexts. Thus, this section describes how EE characteristics influence businesses' strategic decisions.

The EE is a macro-level concept with relevant micro-level implications (Acs et al., 2014). The usefulness of resources and knowledge relies in the capacity of firms to access and use them as they 
flow through social networks. Notice that the density of social networks is critical as it determines knowledge flows about new opportunities, new technologies, and the entrepreneurship process more generally (Spigel and Harrison, 2018). Thus, the process through which resources flow within a focal EE is key to understanding businesses’ capacity to enhance their competitive edge.

The approach proposed by Spigel and Harrison (2018) offers insights to grasp the connection between EEs and firm competitiveness. In their approach, the EE is analyzed along two dimensions: available resources and network strength (network density). For these authors, resources available in an EE may produce two conditions: 'munificence' which represents an ecosystem with abundant resources; and 'sparseness' which refers to an EE lacking these resources. Similarly, the network strength can produce two conditions: 'well-functioning' (dense networks among entrepreneurs, investors, advisors, and other key agents); and 'poorly functioning' (EEs with a deficient networks).

These properties lead to formulate a $2 \times 2$ matrix with four types of ecosystems (Spigel and Harrison, 2018): (1) 'Strong' EE characterized by munificent resources and well-functioning networks, (2) 'Arid' EE with sparse resources and well-functioning networks; (3) 'Irrigated' EE showing munificent resources and a poorly functioning network; and, (4) 'Weak’ EE characterized by sparse resources and poorly functioning networks.

Both available resources and network strength are vital for firm competitiveness mostly because the access and exploitation of resources will likely translate into superior competitiveness (Spigel and Harrison, 2018). This argument matches the Kirznerian approach to entrepreneurship (Kirzner, 1973) that emphasizes the relevance of efficient mobilization and resource allocation for successful entrepreneurship processes (Lafuente, Acs et al., 2020).

Productive entrepreneurship is more likely to take place in more consolidated EEs. In this sense, Stam and van de Ven (2021) found that the prevalence of high-growth firms in a region is related to the quality of its EE. Similarly, Lafuente et al. (2017) reported that environments with a dynamic industrial fabric and strong institutions are conducive to productive entrepreneurship among Spanish manufacturers and knowledge-intensive service firms. In their study of 121 European regions and 401 German counties respectively, Horváth and Rabetino (2019) and Wyrwich (2019) found that settings with supportive institutions and consolidated EEs facilitate resource exploitation, as well as the creation of knowledge-intensive service businesses.

This theory and evidence give ammunition to the argument that interactions between economic agents and their institutional context affect businesses’ strategy making (Acs et al., 2014). The components of the EE affect how firms strategize competitiveness-enhancing processes by exploiting resources available in the national EE (Lafuente et al., 2017; Horváth and Rabetino, 2019). 
At this point, a relevant issue is how to operationalize businesses' strategy making. From an organizational perspective, recent studies portray competitiveness as a multidimensional construct where different resources interact (e.g., Lafuente, Leiva et al., 2020; Newbert, 2007; Sirmon et al., 2010). In this discussion, the operationalization of firms' strategic approach is often linked to the prioritization of competitive strengths on the basis that their effective exploitation is conducive to superior competitiveness (Sirmon et al., 2010). Underlying this theory is the presumption that competitiveness-enhancing strategies take place in environments that facilitate the access and effective use of resources. However, the outcomes of businesses' strategic choices are affected by multiple factors that interact within the national EE (Acs et al., 2014). That is, businesses operating in weak EEs would face difficulties to effectively implement competitiveness-enhancing strategies.

It is plausible that, in contexts with a consolidated EE, the stock of resources available to firms is greater, and business competitiveness is connected to strategies that prioritize those resources more connected to the business' source of competitive advantage. On contrary, in contexts with an underdeveloped EE, firms’ capacity for implementing competitiveness-enhancing strategies would be undermined by the low availability of key resources and, consequently, these strategies would not produce the desired outcomes in terms of superior competitiveness levels.

This theory and evidence lead us to hypothesize the following:

H2: The quality of the EE-quantified via complex index metrics-is related to strategies that prioritize the exploitation of key resources and business competitiveness.

To sum up, systemic relationships are at the heart of EEs (Stam, 2015). Resource mobilization increases in healthy, functional EEs; and this contributes to a more efficient interaction between new and incumbent businesses and their institutional context which, ultimately, has implications for both entrepreneurs and organizations (Acs, et al., 2014, Lux et al., 2020; McGowan et al., 2011).

\section{Characterizing the entrepreneurial ecosystem in France, Spain, Hungary and Costa Rica}

This section briefly describes the main features of the EE in the analyzed countries, namely France, Spain Costa Rica, and Hungary. We are aware that profiling EEs is a complex task, mostly because of the difficulties to fully understand the multiple interactions that take place among the agents involved in the EE, namely institutions, organizations and individuals (e.g., Acs et al., 2014; Brown and Mawson, 2019).

For the purposes of this study, the characterization of the analyzed EEs is based on information obtained from the European Commission (2019) and from OECD reports dealing with institutional development, SMEs and entrepreneurship (OECD, 2019 and 2020). A summary of the main 
properties of the entrepreneurial context for the select countries is presented in Appendix 1. Also, we use the results of the Global Entrepreneurship Index (GEI) 2018 made available by the Global Entrepreneurship and Development Institute (GEDI: www.thegedi.org) (Acs et al., 2018).

In the specific case of the GEI, notice that this composite indicator was created by Acs et al. (2014) in an effort to generate a solid, theory-grounded index that measures the quality of countries' entrepreneurial ecosystem. Instead of focusing on R\&D processes or entrepreneurship outcomes, underlying the computation of the GEI is the structure of the national system of entrepreneurship that affects technical change at country level. The analysis of EEs based on the GEI provides a rich framework to understand how entrepreneurship and the interactions between individuals and the context nurture economic performance (Lafuente, Acs et al., 2020). For the analyzed countries, summary results for the 14 pillars included in the calculation of the GEI are presented in Appendix 2. The 14 GEI indicators were grouped into two categories: resources and networks.

France is the first study case. France's entrepreneurial ecosystem is characterized by strong institutions supporting entrepreneurs and SMEs which are coupled with solid networks between businesses, potential shareholders and other stakeholders including potential entrepreneurs and support agencies (European Commission, 2018a; OECD, 2019).

The access to both networks and a homogeneous regulatory framework facilitates the identification and exploitation of business opportunities as well as new venture creation processes (Kingsley and Malecki, 2004). Additionally, the country enjoys well developed physical and digital infrastructures that support both SMEs' operations-in local and digital markets—and the access to resources that explain innovative patterns reported by French SME sectors (Acs et al., 2018).

In the case of Spain, García-Tabuenca et al. (2011) highlight that the country’s decentralized structure affects the internal configuration of the national EE. In Spain, some regions have stronger entrepreneurial activity due to region-specific factors, including historical circumstances, and regional policies. Consequently, the combination of these factors results in regions with high entrepreneurial dynamism (e.g., Madrid, Catalonia and Valencia), while other regions show medium dynamism (e.g., Galicia, Asturias and Cantabria) and low entrepreneurial dynamism (the two Castile regions, Extremadura, Andalusia, and Murcia) (García-Tabuenca et al., 2011). Spain’s $\mathrm{EE}$ is in the process of consolidation are greater maturity is needed to overcome structural weaknesses (Peña-Legazkue et al., 2019).

Spain presents weaknesses in seven out of the 12 factors used to qualify its entrepreneurial environment (e.g., funding, innovation, support policies, and business networking). On contrary, high valuations were reported for physical infrastructure, government programs, social and cultural norms and entrepreneurial training in tertiary education (European Commission, 2018b). Díaz- 
Santamaría (2016) considers that Spain's EE requires further consolidation as large cities-i.e., Madrid and Barcelona-support the formation of start-ups. In this sense, the Startup Ecosystem Overview (MWC, 2019) reports that differences in the EE across Spanish regions explain the distribution of entrepreneurial activity and business density: 65\% of firms is located in Madrid and Barcelona, while 8.5\% in the emerging areas of Valencia and Bilbao. According to this report, Spain has nearly 200 business incubators and 129 co-working spaces.

Concerning Hungary, after the introduction of market reforms in the early 1990s the number of SMEs increased rapidly, doubling in size in just 5 years (1991-1996) (Szerb et al., 2017). According to Győri et al. (2019), Hungary still presents characteristics of a post-communist society, whose roots have marked the development of both the socio-economic environment and the innovative culture of SMEs.

In this scenario, the European Union (European Commission, 2018c) highlights the improvement in the ability of local SMEs to bring innovative products and services to the market as one of the top priority aspects that Hungarian administrations should address. Although improved local cultural support and the relatively strong connections between Hungarian SMEs, another critical area that requires attention by policy makers is the development of support actions that improve both local market competition and the access to financial resources, as well as the realization of joint projects between SMEs and R\&D centers (European Commission, 2018c).

In Costa Rica, the embryonic EE is supported by a strong institutional framework but networks are still limited. Costa Rica's Government backed the national EE by formally launching the National Entrepreneurship Policy in 2010 and creating the National Network on Incubators and Accelerators (MEIC, 2010). Further policy efforts led to introduce entrepreneurship support actions in 2014 (MEIC, 2014). Although 79 Costa Rican institutions form the SME Support Network and the National Network of Incubators and Accelerators (MEIC, 2019) ${ }^{2}$, the development of a solid business-to-business network is a key area that should be developed by policy makers (OECD, 2020). Access to finance is supported by 14 institutions; however, these public agencies mostly target firms in the development and growth stages of the life cycle. Six public agencies focus on innovation-related support measures for firms at any stage of the life cycle. Overall, the Costa Rica's EE is progressively evolving and, despite recent efforts by public administrations, further actions linked to the activation of support measures are needed to improve both the country's dispersed ecosystem and the limited connectivity between economic agents.

\footnotetext{
2 The report included 58 actors, 50\% public, 47\% private, and 3\% of mixed character. The activities carried out by each actor were classified into two major areas: a) business life cycle (entrepreneurial culture, gestation, start-up, development-growth and maturity) and (b) categories/activities within ecosystem (policy, support, financing instrument, innovation and market).
} 
Building on the conceptual taxonomy of Spigel and Harrison (2018), Figure 1 proposes a categorization of the four analyzed EEs (Appendix 2 presents the breakdown of the Global Entrepreneurship Index (GEI) 2018 for the selected countries). Following Spigel and Harrison (2018), the 14 GEI indicators were grouped in two categories: resources and networks. The result of the GEI scores suggests that France presents the healthiest EE (GEI= 64.09), followed by Spain (GEI= 45.30), Hungary (GEI= 36.26) and Costa Rica (GEI= 33.30) (Acs et al., 2018).

According to the global ranking of the GEI (2018), out of a total of 137 nations, France was ranked 10, Spain is in the 34th position, whereas Hungary is ranked 50 and Costa Rica is the 56th country in the GEI ranking (Costa Rica is atop Latin America: GEI ranking: 6 out of 24 countries).

----- Insert Figure 1 about here -----

France shows the highest GEI indicators for both resource- and network-related variables (Appendix 2). Also, France presents the most balanced EE among the analyzed countries, in terms of GEI variables. The highest GEI pillar values are technology absorption (0.941), opportunity startup (0.941), and process innovation (0.891) (Appendix 2). On contrary, the weakest pillars of France’s EE are startup skills (0.451) and opportunity perception (0.469).

Spain reports the highest GEI indicators for network-related variables: technology absorption (0.75), risk acceptance (0.663) and networking (0.624), while the lowest values are observed for resource-related variables: internationalization (0.264), high growth (0.269) and product innovation (0.317) (Appendix 2). Furthermore, the average result for the network variables (0.53) is higher than that observed for resources (0.43).

The EE in Hungary and Costa Rica is characterized by low access to entrepreneurial resources and developing networks, compared to the results for France and Spain. In the case of Hungary, the highest GEI values are reported for network-related variables: opportunity start-up (0.562) and technology absorption (0.495); while product innovation (0.253) (a resource-related variable) and risk acceptance (0.168) (a network-related variable) are the weakest pillars of Hungary's EE (Appendix 2). The results for Costa Rica's EE show that the highest GEI score was reported for start-up skills (0.723) (a resource-related variable), followed by two network-related indicators: cultural support (0.462) and opportunity perception (0.411).

From the qualitative description of the four EEs and the results of the GEI indicators presented above, following Spigel and Harrison (2018) it is suggested that France has a 'Strong' EE, Spain’s EE can be classified as 'Irrigated', whereas Hungary's EE is 'Arid', and Costa Rica presents a 'Weak' ecosystem. Despite high rates of entrepreneurship and resources, Spigel and Harrison 
(2018) indicate that 'irrigated' EEs are characterized by poorly functioning or developing networks that prevent entrepreneurial learning, knowledge sharing and cooperation among agents; conditions that may arise in Spain's EE. In territories with a 'weak' ecosystem there is limited network connectivity and slight development of resources, characteristics that reflect the reality of the EE in Hungary and Costa Rica.

\section{Data, variable definition and efficiency computed via the 'benefit of the doubt' method}

\subsection{Data}

The empirical illustration employs a unique dataset drawn from an international research project on firm competitiveness (Global Competitiveness Project, GCP: www.sme-gcp.org) developed by the Polytechnic University of Catalonia (UPC Barcelona Tech, Spain) and the University of Pécs (Hungary). In 2020, universities from ten European-i.e., Bosnia, Czech Republic, France, Hungary, Spain, and Russia—and Latin American—i.e., Brazil, Colombia, Costa Rica, and Mexico - countries participate in the GCP. The objective of the GCP is to analyze business competitiveness by using composite indicators (Lafuente, Leiva et al., 2020). Recent work by Alonso-Ubieta and Leiva (2019), Bayon and Aguilera (2020), Lafuente, Leiva et al. (2020), and Horváth and Lafuente (2020) further corroborate the validity and robustness of the GCP databases.

Data collection process was entirely supervised by the team working in each participating university. In each country, the selection process of the surveyed firms was two folded. First, each participating team identified businesses operating in different industries. In this stage, top managers are the relevant respondent group, and after an initial telephone call for approval with the owners or top manager an appointment was set. In the second step a face-to-face interview was carried out to one of the owners (only if he/she is in top management team) in the case of businesses with less than 20 employees, while a top manager was interviewed in firms with more than 20 employees. The data collection process was achieved through self-administrated, structured interviews where managers were asked to answer essentially close questions. The survey was conducted by team members, and the data was collected between March and June 2019. The questionnaire used by GCP teams is homogeneous for enhanced comparability of results.

Because of their relevance for the consolidation of knowledge-based economies (Lafuente et al., 2017; 2019; McGowan et al., 2011), this study focuses on the competitiveness analysis of manufacturers and knowledge-intensive business services (KIBS) firms. KIBS firms are innovation bridges that interplay with other economic agents acting as purchaser, provider or partner (Cusumano et al., 2015). KIBS firms show a distinctive way to access, create and integrate knowledge in their processes (Cusumano et al., 2015; Lafuente et al., 2018). Recent studies 
underline the importance of EEs in promoting economic relationships between KIBS and manufacturing firms (Horváth and Rabetino, 2019; Lafuente et al., 2017; Wyrwich, 2019).

According to the European Commission (2012), KIBS firms cover a wide range of activities, including computing, information and communication technologies (NACE Rev-2: 62); architectural and engineering technical services (NACE Rev-2: 71); research and development (NACE Rev-2: 72); as well as business-oriented services (NACE Rev-2: 69, 70, 73 and 78)—i.e., legal and accounting and auditing services, management consultancy, advertising and market research—and other knowledge-oriented services (NACE Rev-2: 74).

The final sample comprises data for 348 firms: 79 Costa Rican firms (47 manufacturers and 32 KIBS firms), 83 French businesses (53 manufacturers and 30 KIBS firms), 92 Spanish firms (52 manufacturers and 40 KIBS firms), and 94 Hungarian firms (62 manufacturers and 32 KIBS firms).

\subsection{Business competitiveness index}

Instead of employing aggregate metrics to evaluate the individual contribution of various competitiveness-related variables, this study follows the methodology proposed by Lafuente, Leiva et al. (2020) to measure competitiveness via a composite indicator. The business competitiveness index includes 46 variables linked to different resources and capabilities that define the ten competitive pillars (Details on the 46 variables that make up the index are presented in Appendix 3). The ten selected pillars match postulates of the resource-based theory of the firm (Barney, 2001; Newbert, 2007; Wernerfelt, 1984), and their relevance flows from the recognition that their interactions shape competitiveness. Respondents were asked to rate the importance of each variable using a 5-point Likert scale in which 1 represents low relevance, 4 represents high relevance, and 0 indicates that the focal variable has no strategic value whatsoever for the firm.

Compared to alternative metrics based on accounting figures that only proxy one dimension of financial or economic performance, composite indicators offer a solution to criticism reported in prior research related to measurement issues as well as the poor matching between the focal variable and the analyzed construct showed by conventional ratios (see the recent work by Greco et al. (2019) for a comprehensive survey on composite indicator building methods).

Concerning the measurement issues, the proposed division of the positive scale values (from 1 to 4) allows a sufficient degree of differentiation in the valuation of the variables used to compute the competitiveness index (Lederer et al., 2013). Additionally, it should be kept in mind that, to ease readability for respondents, the coding of some variables was modified as a result of the nature of the questions. For the 'Human Capital' pillar, numerical values were used to codify the educational attainment of employees (number and share of employees with higher education degree) and the 
proportion of employees participating in training programs. Similarly, the ratio of new product's sales divided by total sales was used in the 'Product Innovation' pillar, while the number of cooperation and innovation agreements was introduced in the 'Networks' pillar. The 'Competitive Strategy' pillar includes the number of economic activities (NACE codes) as a proxy variable for the diversification strategy of the business. Finally, the proportion of sales in foreign markets was included in the 'Internationalization' pillar (Appendix 3).

In the case of the arguments related to the need of using performance metrics that match the analyzed construct, it should be noted that by employing a composite indicator to assess business competitiveness we acknowledge the multidimensionality of this performance construct. This way, the approach adopted in this study is consistent with theoretical approaches rooted in strategic management (e.g., Newbert, 2007; Wernerfelt, 1984).

To calculate the CI, the five-step methodology proposed by Lafuente, Leiva et al. (2020) was followed. First, a set of 46 normalized variables $\left(x_{i j}^{*}=x_{i j} / \max \left(x_{j}\right)\right.$, where $j=1, \ldots J$ and $\left.J=46\right)$ is used to build the 10 pillars that shape the CI. Second, the 10 CI pillars $\left(v=\left(v_{1}, \ldots, v_{10} \in R_{+}^{v}\right)\right.$ are computed as the average of the normalized variables $(j)$ included in each pillar $(\mathbf{v}): p_{i v}=$ $\sum_{J_{v}=1}^{J_{v}} x_{i v}^{*} / J_{v}$ and $p_{i v}^{*}=p_{v} / \max \left(p_{v}\right)$, where $v=1, \ldots, 10$ and $j_{v}=1, \ldots, J_{v}$. Pillar scores $\left(p_{i v}\right)$ are computed at firm-level $(i=1, \ldots, N)$ and the number of variables used to estimate each pillar $\left(j_{v}=1, \ldots, J_{v}\right)$ varies across pillars $(\mathbf{v})$.

Third, the marginal effect resulting from improving each pillar $\left(p_{i v}\right)$ was equalized to estimate the magnitude of the adjustment for each pillar as (estimation of the root for $\delta$ ): $y_{i v}=p_{i v}^{* \delta}$, where $\sum_{i=1}^{N} p_{i v}^{* \delta}-N \overline{y_{v}}=0$. The term $\delta$ is the adjustment magnitude for pillar $v$, that is, the $\delta$ moment that equalizes $p_{i v}^{* \delta}$ at the mean of the focal pillar $\left(\overline{y_{v}}\right)$. Step four adds the penalty of bottleneck in order to consider the connections between CI pillars. Mathematically, the penalty of bottleneck is modeled via a correction form of the exponential function $a e^{-b x}$ (Tarabusi and Guarini, 2013). The penalty function has the form $h_{i, v}=\min \left(p_{i, v}^{*}\right)+\left(1-e^{-\left(p_{i, v}^{*}-\min \left(p_{i, v}^{*}\right)\right)}\right)$, where $h_{i, v}$ is the postpenalty value for the $v$ th pillar and $\min \left(p_{i, v}^{*}\right)$ is the lowest pillar value reported for the ith firm.

Finally, the fifth step uses the values obtained for each aggregate pillar to estimate the CI: $\mathrm{CI}_{\mathrm{i}}=\sum_{\mathrm{v}=1}^{10} p_{i v}^{*}$

Table 1 presents, for each country, the descriptive statistics of the ten analyzed competitive pillars that form the CI as well as for the rest of variables used in this study. 
4.3 Operationalization of strategies: Analysis of composite indicators (CIs) based on the Benefit of the doubt (BOD) weighting model

Summarizing a number of variables into a single CI entails making judgments about the importance of each variable, and the difficulty of this task increases with the number of alternatives. The competitiveness index presented in Section 4.2 quantifies the overall level of competitiveness for each business ( $i)$ as the weighted sum of 10 pillars $(v)\left(\sum\left(w_{v} \times p_{i v}^{*}\right)=C I_{i} \forall w_{v}=1 / 10\right)$. This weighting system reflects a value judgment on what the optimal configuration of competitiveness constituents is. This approach—based on homogeneous (across firms) and fixed (across pillars) weights-ignores firm-specific heterogeneity which may obscure strategic analyses. By construction, additional resources to improve competitive pillars (raw data) would produce the same quantitative improvement in the CI score. Without objective guidance managers will likely follow discretionary criteria to allocate additional resources, and the quantity improvement in competitiveness will be interpreted as good news. Nevertheless, if managers are given more objective, non-arbitrary information about the importance of competitive pillars, resource allocation should follow a more economically meaningful process. Quantity improvements are ensured if additional resources are deployed; however, for an equal quantitative change in the CI, competitive improvements will be qualitatively superior if managers target a clear set of strategic priorities.

The CI presented in Section 4.2 has attractive properties as well as a strong informative capacity that certify its accuracy to measure business competitiveness. But, the homogeneous weighting scheme of this index limits the capacity to identify the strategic aspects that firms should prioritize in order to improve resource allocation and, subsequently, their competitiveness level. This is the core of this study.

In light of the importance of weights both for computing CIs and for identifying key indicators and strategic priorities, the analysis proposed in this research seeks to evaluate the competitive level of firms operating in different countries with different EEs with the objective to clarify how firms can implement optimal competitiveness-enhancing strategies in different contexts.

To achieve this objective the benefit-of-the-doubt (BOD) model is employed (e.g., Cherchye et al., 2007). Rooted in data envelopment analysis (DEA) techniques, the BOD model—originally proposed by Melyn and Moesen (1991) and further developed by, among others, Cherchye et al. (2007) and Sahoo et al. (2017) — is a special case of the input-oriented DEA model (Charnes et al., 1978) with a single constant input (Lovell and Pastor, 1999). Appendix 4 presents the description of the DEA methodology. 
The BOD weighting model is among the methodological approaches recommended by the OECD (2008) for computing composite indicators (CIs). Furthermore, recent studies in the business field using the BOD method further corroborate the validity of this tool for assessing relevant multidimensional metrics at firm level. The BOD method was designed for determining strategic priorities among a set of units of analysis by computing endogenous weights for the analyzed variables (Cherchye et al., 2007). Compared to more canonical analyses based on singledimensional ratios, the use of models based on linear programming - in our case, the BOD method) - to analyze CIs may prove itself efficient for revealing valuable insights on the businessspecific factors driving the focal CI. This is especially relevant in cases where information on the relative importance (i.e., weight) of the analyzed variables is limited.

This way, an analysis based on the BOD method offers more detailed information on the drivers of the CI by evaluating the strengths and weaknesses of the variables shaping the studied multi-dimensional construct (in our study, business competitiveness).

Concerning existing work using BOD models, notice that literature dealing with the BOD method has evolved over time in two main directions. First, early work using BOD models focused on the study of specific policies and the analysis of CIs at country level (see, e.g., the work by Cherchye and colleagues (2007 and 2008)). This research strand also includes, among others, the studies by Mizobuchi (2014) who analyzes the OECD's 'better life' index, and the studies by Araya-Solano (2019) and Lafuente, Araya et al. (2020) who assess the drivers of county competitiveness using index numbers in a developing setting (Costa Rica).

Second, recently an increasingly growing research stream emphasizes the value of the BOD method for evaluating business-level multi-dimensional metrics (i.e., composite indicators), relative to ratio analyses which often offer partial information on the studied phenomenon. Research in this tradition includes studies evaluating firms operating in developing economies-e.g., Sahoo et al. (2017) who analyze the performance (i.e., CI) of management schools in India, and Alonso-Ubieta and Leiva (2019) who study business competitiveness (measured via CI) among Costa Rican businesses-as well as work that scrutinizes multi-dimensional performance metrics for businesses located in developed settings (see, e.g., Horváth and Lafuente (2020) who evaluates business competitiveness (CI) of Spanish firms). Additionally, in their study of 103 KIBS firms operating in four developed and developing countries (Colombia, Costa Rica, Hungary and Spain), Lafuente, Leiva et al. (2020) evaluate how the internal configuration of strategic competencies (i.e., strengths and weaknesses) condition competitiveness (CI) in small viz.-à-viz. medium and large businesses.

From a methodological view point, formally the BOD model considers the selected outputs (in our case, competitive pillars) and employs a set of endogenous, firm-specific weights (w) to 
compute the weighted average of indicators $(\mathbf{y})$ that maximize the CI score $\left(C I_{i}^{B O D}\right)$. Therefore, the BOD model generates, for each business (i), the optimal weighting configuration of competitive pillars by identifying the relative strengths and weaknesses of the output set. Without information about the exact weights of the outputs (y), the BOD weighting assigns to each business the best possible weight configuration (w) which leads to unveil endogenous (firm-specific) strategic priorities, in terms of competitive pillars.

At this point, two methodological aspects are worth mentioning. First, for enhanced estimation accuracy all BOD models are estimated at industry level (i.e., manufacturing and KIBS sectors) and for each country separately. This way, the BOD model acknowledges both industry-specific and country-specific factors that may shape the prioritization of competitiveness-enhancing strategies.

Second, for the purposes of this study, the ten CI pillars (equation (1)) are grouped into four outputs $\left(\mathbf{y}=y_{1}, \ldots, y_{k} \wedge K=4\right)$ as follows: y1: 'Human capital' (human capital pillar); y2: 'Markets' (domestic market and internationalization pillars); y3: 'Innovation' (product innovation and technology pillars); and, finally, y4: 'Strategy' (including the pillars networks, marketing, online presence, decision-making and strategy). Because the industry-specific samples are relatively small, the proposed BOD specification with four outputs seeks to reduce the potential loss of discriminatory power of BOD models with large numbers of inputs and/or outputs, relative to the number of units. ${ }^{3}$ Table 2 presents summary statistics for the output set used in this study.

To further validate the internal consistency of the output set (y), a robustness check based on the Cronbach's alpha statistic was carried out. Results in Appendix 5 confirm the validity of the output set. ${ }^{4}$ Also, the internal consistency of the ten CI pillars was evaluated. The results of the Cronbach's alpha follow: French sample $=0.9608$, Spanish sample $=0.8507$, Hungarian sample $=$ 0.9115 and Costa Rican sample $=0.8271$. These findings confirm that the CI pillars efficiently measure the analyzed construct among the sampled firms (Nunnally and Bernstein, 1994).

----- Insert Table 2 about here -----

The following linear program solves the BOD weighting problem and computes the optimal CI value for each firm (i):

$C I_{i}^{B O D}=\max _{w, k} \sum_{k=1}^{K} w_{i k} y_{i k} \quad k=1, \ldots, K=4 \quad i=1, \ldots, N$

\footnotetext{
${ }^{3}$ Within the literature dealing with non-parametric frontier models, Banker et al. (1989) suggested a 'rule of thumb' to ensure the discriminatory power of DEA models: the number of observations should be at least three times the number of inputs $(\mathbf{k})$ and outputs $(\mathbf{y})(N \geq 3 \times(\mathbf{y}+\mathbf{k}))($ Cook et al., 2014, p. 2).

${ }^{4}$ All values for the Cronbach's alpha are above 0.70. For the 'human capital' output (y4), the Cronbach's alpha statistic is not computed because this output includes only one pillar of the competitiveness index.
} 
subject to:

$$
\begin{aligned}
& \sum_{k=1}^{K} w_{i k} y_{i k} \leq 1 \\
& w_{i k} \geq 0 \\
& L_{k} \leq \frac{w_{i k} y_{i k}}{\sum_{k=1}^{K} w_{i k} y_{i k}} \leq U_{k}
\end{aligned}
$$

Equation (2) computes for each firm a vector of endogenous weights for the four outputs $\left(w_{k}=w_{1}, \ldots, w_{4}\right)$ that maximizes the CI. The CI performance value is bounded $\left(C I_{i}^{B O D} \leq 1\right)$ : for efficient firms $C I_{i}^{B O D}=1$, while for inefficient businesses $C I_{i}^{B O D}<1$ and $1-C I_{i}^{B O D}$ is the degree of inefficiency (i.e., the output expansion required to be fully efficient). Weights are constrained to be non-negative, which makes $C I_{i}^{B O D}$ a non-decreasing function of the output set (y) (equation (2)). This constraint allows for extreme scenarios that render BOD results inaccurate (e.g., high number of artificially efficient firms). Thus, additional restrictions on the weights are needed in order to account for the relative importance of all CI outputs. Thus, a 'pie share' restriction was added: $L_{k} \leq \frac{w_{i k} y_{i k}}{\sum_{k=1}^{K} w_{i k} y_{i k}} \leq U_{k}$. This restriction is attractive because pie shares $\left(w_{i k} y_{i k}\right)$ do not depend on measurement units and they directly reveal the individual contribution of each pie share to the CI, while allowing for weight heterogeneity within and between firms. In equation (2), $L_{k}$ and $U_{k}$ are the lower and upper limit set for each pie share, respectively. Note that the endogenous weights are business- specific and the sum of the pie shares equals the CI score $\left(C I_{i}^{B O D}\right)$ (equation (2)).

In a closely related manner, notice that equation (2) assumes that all outputs are relevant for business competitiveness and firms will prioritize competitiveness maximizing pillars. Finally, all BOD models were computed using the GAMS@ software.

\section{Results}

This section presents the results of the study. Section 5.1 focuses on the relationship between the EE and firm competitiveness, while Section 5.2 evaluates the strategic choices adopted by the sampled firms. The CIs were computed based on the BOD model (equation (2)) and summary results are presented in Table 3. Also, Appendix 6 show the results of the Kolmogorov-Smirnov test of equality of distributions comparing the BOD scores for the four analyzed countries and distinguishing firms operating in manufacturing and KIBS sectors.

Overall, results in Table 3 indicate that the distribution of BOD scores among Spanish firms is more oriented toward high efficiency values (closer to unity), compared to results reported for the 
rest of countries. Also, at country-level we notice that, with the exception of the Costa Rican sample, KIBS firms outperform manufacturing businesses (see, Figures A2-A5 in Appendix 7).

Among the sampled countries, the industry-level comparison reveals that Spanish manufacturers report the highest efficiency level, (mean BOD score=0.7081), whereas for KIBS activities French firms show the most efficient results (mean BOD score= 0.7462) (Table 3). This latter result suggests that, in their corresponding EE, KIBS firms are better able to exploit their available resources and achieve superior competitive efficiency levels than manufacturing businesses.

----- Insert Table 3 about here -----

\subsection{The role of the entrepreneurial ecosystem}

A key aspect of this study is to analyze whether the national EE is related to firm competitiveness. To address this point, which is linked to this study's first research question, a multilevel mixed-effects linear regression is used. Because the dataset is nested (businesses nested in countries), a multilevel modeling is preferable to conventional regression models which would likely produce inefficient estimates and biased standard errors (Snijders and Bosker, 2012). The association between firm competitiveness and the national EE can be presented in a model with the following form:

$C I_{i c}^{B O D}=\beta_{00}+\beta_{0 c}+\beta_{1}$ Firm level variables $i c+\beta_{2} \mathrm{GEI}_{c}+\varepsilon_{i c}$

In equation (3), $i$ indexes business and $c$ countries, $\beta_{00}$ is the overall mean of the dependent variable (i.e., BOD scores) and $\beta_{0 c}$ is the randomly distributed country effect, that is, the variance of the mean value of the BOD scores for each country $(c)$ around the overall mean BOD score. The firm level variables include size (ln employees), age (ln years of market experience) and industry (the omitted category is manufacturing) (see Table 1); whereas the country-specific effect (EE) is measured via the Global Entrepreneurship Index (GEI) for 2018 provided by the Global Entrepreneurship and Development Institute (https://thegedi.org). As we indicated above in Section 3, the GEI is a composite indicator developed by Acs et al. (2014) with the objective to assess the quality of countries' entrepreneurial ecosystem. Instead of focusing on R\&D processes or the process of entrepreneurial action, underlying the computation of the GEI is the structure of the national system of entrepreneurship that affects technical change at country level. The analysis of entrepreneurial ecosystems based on the GEI-which focuses on the national system of 
entrepreneurship and its effects on technical change—offers a rich framework to understand how country-level entrepreneurship influence economic performance (Lafuente Acs et al., 2020).

As a necessary pre-requisite, it was verified if the EE (country effect) represents the institutional umbrella backing new and incumbent firms in the economy. To determine the appropriateness of the proposed multilevel model (equation (3)) the between-country variance of the dependent variable was estimated. The results of the intercept-only model (model 1 in Table 4) was used to compute the intra-class correlation coefficient (ICC), that is, the proportion of the total variance in the dependent variable that exists between countries. Results in model 1 indicate that mean competitive efficiency (BOD scores) among countries is 0.6165 (without controlling for business-level covariates), and that there is more variation within countries (0.0374) than among countries (0.0096). The ICC value for model 1 is 0.2043 - which is higher than the commonly accepted rule of thumb of 0.15 (Hox, 2010)—which suggests that 20.43\% of BOD variations lie between the analyzed countries. Consequently, results for model 1 indicate that there is enough between-country variance to justify a multilevel approach.

----- Insert Table 4 about here -----

For the full model (specification 2), the ICC value (0.2501) is larger than that reported for the unconditional model (as expected, given that the model controls for some business-level variation). Results in model 2 indicate that the EE (the country-level effect) has a significant impact on the level of competitive efficiency.

The findings for the EE are in line with the argument that business competitiveness - which is linked to the exploitation of resources and capabilities—varies depending on the characteristics of the institutional setting where organizations are embedded. These arguments and results give support the first hypothesis (H1) stating that a positive relationship exists between the quality of the entrepreneurial ecosystem and firm competitiveness.

\subsection{Business competitiveness assessment based on the BOD model}

So far, the multilevel analysis focused on the link between EE and firm competitiveness. But, in connection to this study's second research question, this section deals with the identification of the strategic paths followed by firms in order to assess if the prioritization of different competitive pillars is conducive to superior competitiveness. Table 5 presents the breakdown of the CI resultsby country and by industry, and distinguishing between top (Q1) and bottom (Q4) performing firms - as well as the firm-specific weights which represent the CI pillars prioritized by firms. 
The findings for the strategic priorities-i.e., endogenous weights estimated via the BOD model—show that businesses prioritize different competitive pillars. At country level, 'human capital' is the only pillar that consistently appears as a top strategic priority if achieving a superior competitiveness level is the desired goal. This result is homogeneous across the analyzed industries.

----- Insert Table 5 about here -----

For the rest of pillars, differences in the prioritization of competitive strategies are evident across industries and across countries. In the case of France, 'markets' is the second output prioritized by KIBS businesses (Wilcoxon signed-rank test $=1.82, p$-value $=0.068$ ), while 'markets' and ‘innovation' are equally adopted by manufacturing businesses in order to enhance their competitive efficiency (Wilcoxon signed-rank test $=-0.98, p$-value $=0.324$ ).

In Spain, 'markets' is the second pillar prioritized by manufacturers; however, the comparison of the weight assigned to the 'markets' and 'innovation' pillars yields a not significant result (Wilcoxon signed-rank test $=-1.30, p$-value $=0.194$ ). On contrary, the strategic choices of Spanish KIBS offer a clearer pathway, and for these firms 'innovation' is the second strategic priority, compared to the weight assigned to the 'markets' pillar (Wilcoxon signed-rank test $=2.54, p$-value $=0.011)$.

The strategic pattern observed for Hungarian businesses indicate that both manufacturing and KIBS firms do not have a clear prioritization strategy. The findings of the Wilcoxon signed-rank test indicate that both the 'markets' and 'innovation' outputs are equally strategic for Hungarian businesses: for manufacturing firms the result of the Wilcoxon signed-rank test $=1.02$ ( $p$-value $=$ 0.306 ) and for KIBS firms the results of the Wilcoxon signed-rank test $=-0.19$ ( $p$-value $=0.852$ ).

Among Costa Rican businesses ‘innovation' is, together with 'human capital', the pillar that should be prioritized in order to optimally enhance competitiveness. Yet, the comparison of the weights assigned to the 'innovation' and 'markets' pillars suggest that Costa Rican manufacturers and KIBS do not follow a clear strategic path (Wilcoxon signed-rank test for manufacturers $=-0.19$, $p$-value $=0.849$; Wilcoxon signed-rank test for KIBS $=-0.49, p$-value $=0.627$ ).

Once we distinguish top (upper quartile) from poor performing (bottom quartile) firms (Table 5), differences in the strategic path followed by businesses becomes more evident.

The findings indicate that, jointly with 'human capital', 'innovation' is the strategic priority of French and Spanish top performing KIBS firms. For each country, the comparison between the endogenous weights computed for the pillars 'innovation' (second strategic priority) and 'markets' 
(third strategic priority) verifies these results: Wilcoxon signed-rank test for French KIBS = 1.77 ( $p$ value $=0.079)$; and Wilcoxon signed-rank test for the Spanish KIBS $=2.15(p$-value $=0.032)$.

For manufacturing businesses, the weight assigned to the 'markets' and 'innovation' pillars is not significantly different, thus indicating that these outputs are equally prioritized by these firms.

A similar finding was found for Hungarian and Costa Rican businesses. That is, regardless the industry and the competitive efficiency level (top or bottom), the findings of the Wilcoxon signedrank test indicate that firms in these countries give an equally relevant weight to 'markets' and to 'innovation' strategies. ${ }^{5}$

The findings of this analysis indicate that French and Spanish firms seem to operate in a more consolidated EE which may contribute to better materialize-in terms of superior competitive efficiency - the strategic efforts associated to the prioritization of competitive pillars. This is specially the case of KIBS firms. On contrary, the strategic path of Hungarian and Costa Rican firms is less clear; and the similarities found in the configuration of competitive pillars between high and low competitive firms suggest that the properties of the embryonic EE in these two countries (Hungary and Costa Rica) may tamper businesses' efforts for adopting competitiveenhancing strategies. These results and arguments are in line with the second hypothesis (H2) stating that the quality of the national EE is related to the relationship between the adoption of specific strategies that prioritize the exploitation of key resources and business competitiveness.

\section{Concluding remarks, implications and future research lines}

\subsection{Concluding remarks}

This study proposes that the EE is a relevant factor explaining differences in business competitiveness. Furthermore, we argued that the effectiveness of businesses' strategic choices can be conditioned by the characteristics of the national EE. By analyzing a sample of 348 manufacturing and KIBS firms operating in four different settings-namely, France, Spain, Hungary and Costa Rica—for 2019, the core findings of the study indicate that the quality of the EE (measured via the GEI index) is related to business competitiveness, computed via the 'benefit of the doubt' method. The results also suggest that businesses operating in more consolidated

\footnotetext{
${ }^{5}$ For Hungarian top performing firms: Wilcoxon signed-rank test for manufacturers $=1.57(p$-value $=0.161)$; and Wilcoxon signed-rank test for KIBS $=-0.14$ ( $p$-value $=0.889)$. For Hungarian poor performing firms: Wilcoxon signed-rank test for manufacturers $=0.51(p$-value $=0.609)$; and Wilcoxon signed-rank test for KIBS $=0.98(p$-value $=0.327)$. For Costa Rican top performing firms: Wilcoxon signed-rank test for manufacturers $=0.41(p$-value $=0.683)$; and Wilcoxon signed-rank test for KIBS $=-0.31(p$-value $=0.753)$. For Costa Rican poor performing firms: Wilcoxon signed-rank test for manufacturers $=-0.71(p$-value $=$ $0.480)$; and Wilcoxon signed-rank test for KIBS = -1.52 ( $p$-value $=0.128)$.
} 
ecosystems are better able to fully realize the positive effects of strategic choices that seek to prioritize and exploit key resources and capabilities.

In this study, competitiveness is conceptualized as a multidimensional construct that results from the mutually dependent associations between resources and capabilities. Understanding the drivers of competitiveness is at the heart of strategic management. From an organizational view point, the novelty of our work relies in the analysis of competitiveness via the BOD model seeking to identify how businesses operating in different contexts can achieve superior competitiveness levels by orchestrating different resources and capabilities. Additionally, the results presented in this study are consistent with recent work highlighting the relevance of the EE in shaping both territorial and different business-level outcomes (e.g., Acs et al., 2014; Lafuente, Acs et al., 2020; Spigel, 2017). From a policy perspective, the analysis proposed in this study may offer guidance to policy makers on how to support local firms by implementing specific policies that, in turn, may contribute to enhance the quality of the national EE.

\subsection{Implications}

In light of the results of this study, what implications can be drawn from the analysis? The implications presented in this section are strictly connected to the study's research questions.

Academic implications.-From an academic perspective, the analysis proposed in this study constitutes a valid case to illustrate the potential effects of EEs on business outcomes. Even though the logic underlying the analytical framework of this study is more connected to the Kirznerian approach to entrepreneurship (Kirzner, 1973; Lafuente, Acs et al., 2020), the findings supporting a connection between EEs and business competitiveness validate existing work linking EEs and different metrics of entrepreneurship and business performance (see, e.g., Lafuente et al., 2017; Horváth and Rabetino, 2019); as well as open the door for developing more theory within the EE frame in a direction where the study of the performance trajectory of firms operating in different EEs plays a central role. This idea is connected to the first research question of this study ('does the EE affect business competitiveness?').

Implications for strategy makers.-For the strategy practitioner, we suggest that managers should turn their attention to the development of both quantitative-e.g., operational and financial variables — and qualitative metrics — e.g., aspects related to strategy, product and online presencewhen designing competitiveness-enhancing strategies as well as evaluating the business' competitiveness level. Also, the results of our study highlight the importance of internal analyses. Without accurate data that permits the appropriate assessment of the internal system of competencies, competitiveness enhancing strategies would likely turn sterile and would not 
necessarily produce the desired outcomes. By evaluating the configuration of competitive pillars, business managers will be in a better position for understanding the potential value of strategies that emphasize the prioritization of specific strategic aspects as well as for determining the strategy making of the organization.

The value of information for directed policy making.-Entrepreneurial ecosystems are not checklists, and there is no perfect recipe to extrapolate successful EE experiences or policies from one context to another. The comparison of different EEs may offer value for benchmarking purposes and for understanding how specific policies may alter the properties of countries' EE.

Policy makers need accurate information about the different elements of the ecosystem so that they can design economically meaningful actions that improve the EE. In this sense, information obtained from the benchmarking of other, similar contexts may constitute a valuable input. Nevertheless, the results of the study suggest the need to integrate industry- and business-specific data in EE analyses if the adoption of purposeful policies or stimuli that correct weak points of the EE where both institutions and businesses interact is the desired objective.

In connection to the second research question of this study ('do differences in the national EE contribute to explain discrepancies in businesses' competitiveness-enhancing strategies, in terms of the exploitation of businesses' resources and capabilities?'), detailed information at all levels of the EE (i.e., economic agents and institutions) may usefully be made critical to inform policy makers on what support actions are potentially conducive to improve the national EE and, ultimately, to superior economic figures at industry and business level in the short and long run.

\subsection{Future research lines}

The results presented in this study are open to further verification. First, the systemic and dynamic nature of EEs calls for future studies that contribute to better understand the processes through which EE develop and reinvent themselves (Spigel, 2017). For example, future work should examine how existing and new policy interventions affect the functionality and evolution of EEs. Second, similar to prior research (e.g., Horváth and Rabetino, 2019; Lafuente, Acs et al., 2020), our study employs aggregate (country-level) data to describe the main characteristics of the EE among the study countries which may limit the description of the analyzed EEs. In this sense, future research might complement the quantitative data used to characterize EEs with qualitative information in order to more accurately unveil both the properties of the EE as well as policy actions directly affecting the configuration of countries' entrepreneurial ecosystem. By including more detailed, qualitative data into the analysis of EEs, researchers would be better equipped for verifying how certain characteristics of the local EE—which are not entirely captured by aggregate 
data—can impact business outcomes (e.g., competitiveness, economic performance). Third, indepth qualitative studies dealing with the complex connections between specific properties of EEs and business outcomes would contribute to identify the industry- and business-specific effects resulting from the activation of the network ties between economic agents (e.g., entrepreneurs as well as new and incumbent firms) and institutions (Spigel, 2017).

\section{References}

Acs, Z., Szerb, L., Lafuente, E. and Lloyd, A. (2018), Global Entrepreneurship and Development Index 2018, Springer International Publishing (SpringerBriefs in Economics). ISBN 978-3-03003278-4 (Softcover), 978-3-030-03279-1 (eBook), doi: 10.1007/978-3-030-03279-1

Acs, Z.J., Autio, E. and Szerb, L. (2014), "National systems of entrepreneurship: Measurement issues and policy implications”, Research Policy, Vol. 43 No. 3, pp. 476-494.

Acs, Z.J., Stam, E., Audretsch, D. and O’Connor, A. (2017), “The lineages of the entrepreneurial ecosystem approach”, Small Business Economics, Vol. 49 No.1, pp. 1-10.

Alonso-Ubieta, S. and Leiva, J.C. (2019), “Business Competitiveness in Costa Rica: A Multidimensional Approach”, TEC Empresarial, Vol. 13 No. 3, pp. 28-41.

Aral, S. and Weill, P. (2007), "IT assets, organizational capabilities, and firm performance: how resource allocations and organizational differences explain performance variation”, Organization Science, Vol. 18 No. 5, pp. 763-780.

Araya-Solano, M. (2019), “Efficiency assessment of Costa Rica’s counties: A non-parametric analysis of the county competitiveness index”, TEC Empresarial, Vol. 13 No. 3, pp. 78-92.

Asta, D.M. (2021), “Kernel density estimation on symmetric spaces of non-compact type”, Journal of Multivariate Analysis, Vol. 181, pp. 104676.

Audretsch, D., Falck, O., Feldman, M.P. and Heblich, S. (2011), “Local entrepreneurship in context”, Regional Studies, Vol. 46 No. 3, pp. 379-389.

Banker, R.D., Charnes, A., Cooper, W.W., Swarts, J. and Thomas, D. (1989), “An introduction to data envelopment analysis with some of its models and their uses”, Research in Government and Nonprofit Accounting, Vol. 5, pp. 125-163.

Barney, J.B. (2001), "Resource-based theories of competitive advantage: A ten-year retrospective on the resource-based view”, Journal of Management, Vol. 27 No. 6, pp. 643-650.

Bayon, M. and Aguilera, P. (2020), “Managerial perceptions of the strategic relevance of resources and capabilities and its configuration for firm competitiveness: an exploratory study”, Competitiveness Review, in press, doi: https://doi.org/10.1108/CR-01-2020-0023 
Belderbos, R. and Sleuwaegen, L. (2005), "Competitive drivers and international plant configuration strategies: a product-level test”, Strategic Management Journal, Vol. 26 No. 6, pp. 577-593.

Brown, R. and Mason, C. (2017), “Looking inside the spiky bits: a critical review and conceptualisation of entrepreneurial ecosystems”, Small Business Economics, Vol. 49 No. 1, pp. 11-30.

Brown, R. and Mawson, S. (2019), "Entrepreneurial ecosystems and public policy in action: a critique of the latest industrial policy blockbuster”, Cambridge Journal of Regions, Economy and Society, Vol. 12 No. 3, pp. 347-368.

Cao, Z. and Shi, X. (2020), “A systematic literature review of entrepreneurial ecosystems in advanced and emerging economies”, Small Business Economics, in press, doi: https://doi.org/10.1007/s11187-020-00326-y

Cavallo, A., Ghezzi, A., and Balocco, R. (2019). "Entrepreneurial ecosystem research: Present debates and future directions”, International Entrepreneurship and Management Journal, Vol. 15 No. 4, pp. 1291-1321.

Charnes, A., Cooper, W.W. and Rhodes, E. (1978), "Measuring the efficiency of decision making units”, European Journal of Operational Research, Vol. 2 No. 6, pp. 429-444.

Cherchye, L., Moesen, W., Rogge, N. and Van Puyenbroeck, T. (2007), “An introduction to 'benefit of the doubt' composite indicators”, Social Indicators Research, Vol. 82 No. 1, pp. 111145.

Cherchye, L., Moesen, W., Rogge, N., Van Puyenbroeck, T., Saisana, M., Saltelli, A., Liska, R. and Tarantola, S. (2008), “Creating composite indicators with DEA and robustness analysis: the case of the Technology Achievement Index”, Journal of the Operational Research Society, Vol. 59 No. 2, pp. 239-251.

Cook, W.D., Tone, K. and Zhu, J. (2014), “Data envelopment analysis: Prior to choosing a model”, Omega, Vol. 44, pp. 1-4.

Crozet, M. and Milet, E. (2017), "Should everybody be in services? The effect of servitization on manufacturing firm performance”, Journal of Economics and Management Strategy, Vol. 26 No. 4, pp. 820-841.

Cusumano, M.A., Kahl, S.J. and Suarez, F.F. (2015), “Services, industry evolution, and the competitive strategies of product firms”, Strategic Management Journal, Vol. 36 No. 4, pp. 559575.

Díaz-Casero, J.C., Ferreira, J.J.M., Hernández-Mogollón, R. and Barata-Raposo, M.L. (2012), "Influence of institutional environment on entrepreneurial intention: a comparative study of two 
countries university students”, International Entrepreneurship and Management Journal, Vol. 8 No. 1, pp 55-74.

Díaz-Santamaría, C.C, (2016), “Aproximación descriptiva y econométrica del ecosistema del" startups” en España: un análisis de los principales factores de éxito”, PhD Thesis, Universidad de las Palmas de la Gran Canaria, España.

European Commission (2018a). SBA Fact Sheet France. Retrieved from: https://ec.europa.eu/docsroom/documents/32581/attachments/11/translations/en/renditions/native

European Commission (2018b). SBA Fact Sheet Spain. Retrieved from: https://ec.europa.eu/docsroom/documents/32581/attachments/27/translations/en/renditions/native

European Commission (2018c). SBA Fact Sheet Hungary. Retrieved from: https://ec.europa.eu/docsroom/documents/38662/attachments/14/translations/en/renditions/native

European Commission (2019), Evaluation of Support Services for would-be Entrepreneurs and Newly Established Businesses. Luxemburg: Executive Agency for Small and Medium-sized Enterprises (EASME) COSME. PDF ISBN: 978-92-9202-517-5.

Fritsch, M. and Storey, D.J. (2014), “Entrepreneurship in a regional context: Historical roots, recent developments and future challenges”, Regional Studies, Vol. 48, pp. 939-954.

Fuller, J., Jacobides, M.G. and Reeves, M. (2019), “The myths and realities of business ecosystems”, MIT Sloan Management Review, Vol. 60 No. 3, pp. 1-9.

García-Tabuenca, A., Crespo-Espert, J.L. and Cuadrado-Roura, J.R. (2011), “Entrepreneurship, creative industries and regional dynamics in Spain”, Annals of Regional Science, Vol. 47 No. 3, pp. 659-687.

Godley, A., Morawetz, N., and Soga, L. (2021). "The complementarity perspective to the entrepreneurial ecosystem taxonomy”, Small Business Economics, Vol. 56, pp. 723-738.

Greco, S., Ishizaka, A., Tasiou, M. and Torrisi, G. (2019), “On the methodological framework of composite indices: A review of the issues of weighting, aggregation, and robustness”, Social Indicators Research, Vol. 141 No. 1, pp. 61-94.

Grifell-Tatjé, E. and Lovell, C.A.K. (2015), Productivity Accounting: The Economics of Business Performance. Cambridge University Press, New York.

Győri, Á., Czakó, Á., and Horzsa, G. (2019). "Innovation, Financial Culture, and the SocialEconomic Environment of SMEs in Hungary”, East European Politics and Societies, Vol.33, No. 4, pp. 976-1004.

Hansen, J.M., McDonald, R.E. and Mitchell, R.K. (2013), “Competence resource specialization, causal ambiguity, and the creation and decay of competitiveness: the role of marketing strategy 
in new product performance and shareholder value”, Journal of the Academy of Marketing Science, Vol. 41 No. 3, pp. 300-319.

Horváth, K. and Lafuente, E. (2020), “A non-parametric analysis of the effect of the configuration of competitive pillars on competitive efficiency”, Competitiveness Review, in press, doi: 10.1108/CR-12-2019-0143

Horváth, K. and Rabetino, R. (2019), “Knowledge-intensive territorial servitization: regional driving forces and the role of the entrepreneurial ecosystem”, Regional Studies, Vol.53 No. 3, pp. 330-340.

Hox, J.J. (2010), Multilevel analysis: techniques and applications, 2nd ed., New York, Routledge. Isenberg, D.J. (2010), “How to start an entrepreneurial revolution”, Harvard Business Review, Vol. 88 No. 6, pp. 41-50.

Jacobs, W., Van Rietbergen, T., Atzema, O., Van Grunsven, L. and Van Dongen, F. (2016), “The impact of multinational enterprises (MNEs) on knowledge-intensive business services (KIBS) startups: Empirical evidence from the Dutch Randstad. Regional Studies, Vol. 50 No. 4, 728743.

Julien, P.A. and Ramangalahy, C. (2003), “Competitive strategy and performance of exporting SMEs: an empirical investigation of the impact of their export information search and competencies”, Entrepreneurship Theory and Practice, Vol. 27 No. 3, pp. 227-245.

Ketchen, D.J. Jr, Hult, G.T.M. and Slater, S.F. (2007), “Toward greater understanding of market orientation and resource-based view”, Strategic Management Journal, Vol. 28 No. 9, pp. 961964.

Kingsley, G. and Malecki, E.J. (2004), “Networking for competitiveness”, Small Business Economics, Vol. 23 No. 1, pp. 71-84.

Kirzner, I.M. (1973), Competition and entrepreneurship, Chicago: University of Chicago Press.

Lafuente, E., Acs, Z.J., Sanders, M. and Szerb, L. (2020), “The global technology frontier: productivity growth and the relevance of Kirznerian and Schumpeterian entrepreneurship”, Small Business Economics, Vol. 55, pp. 153-178.

Lafuente, E., Araya, M., Leiva, J.C. (2020), “Assessment of local competitiveness: A composite indicator analysis of Costa Rican counties using the 'Benefit of the Doubt' model”, SocioEconomic Planning Sciences, in press, doi: https://doi.org/10.1016/j.seps.2020.100864

Lafuente, E., Leiva, J., Moreno, J. and Szerb, L. (2020), “A non-parametric analysis of competitiveness efficiency: The relevance of firm size and the configuration of competitive pillars”, BRQ Business Research Quarterly, Vol. 23 No. 3, 203-216. 
Lafuente, E. and Rabetino, R. (2011), "Human capital and growth in Romanian small firms”, Journal of Small Business and Enterprise Development, Vol. 18 No. 1, pp. 74-96.

Lafuente, E., Szerb, L. and Rideg, A. (2020), “A system dynamics approach for assessing SMEs’ competitiveness”, Journal of Small Business and Enterprise Development, Vol. 27 No. 4, pp. 555-578.

Lafuente, E. and Vaillant, Y. (2013), “Age Driven Influence of Role-Models on Entrepreneurship in a Transition Economy”, Journal of Small Business and Enterprise Development, Vol. 20 No. 1, pp. 181-203.

Lafuente, E., Vaillant, Y. and Leiva, J.C. (2018), “Sustainable and Traditional Product Innovation without Scale and Experience, but only for KIBS!”, Sustainability, Vol. 10 No. 4, pp. 1169.

Lafuente, E., Vaillant, Y. and Rialp, J. (2007), "Regional differences in the influence of role models: Comparing the entrepreneurial process of rural Catalonia”, Regional Studies, Vol. 41 No. 6, pp. 779-795.

Lafuente, E., Vaillant, Y. and Vendrell-Herrero, F. (2017), “Territorial servitization: Exploring the virtuous circle connecting knowledge-intensive services and new manufacturing businesses”, International Journal of Production Economics, Vol. 192, pp. 19-28.

Lafuente, E., Vaillant, Y. and Vendrell-Herrero, F. (2019), “Territorial servitization and the manufacturing renaissance in knowledge-based economies”, Regional Studies, Vol. 53 No. 3, pp. 313-319.

Lederer, M., Schott, P., Huber, S. and Kurz, M. (2013), Strategic Business Process Analysis: A Procedure Model to Align Business Strategy with Business Process Analysis Methods, S-BPM ONE-Running Processes, Springer, Berlin Heidelberg, pp. 247-263.

Lovell, C.A.K. and Pastor, J.T. (1999), "Radial DEA models without inputs or without outputs”, European Journal of Operational Research, Vol. 188 No. 1, pp. 46-51.

Lux, A.A., Macau, F.R. and Brown, K.A. (2020), "Putting the entrepreneur back into entrepreneurial ecosystems”, International Journal of Entrepreneurial Behavior \& Research, in press, doi: 10.1108/IJEBR-01-2020-0031

Mason, C. and Brown, R. (2014), “Entrepreneurial Ecosystems and Growth oriented Entrepreneurship. Final Report to OECD. Paris: OECD Publishing. Available at: http://lib.davender.com/wp-content/uploads/2015/03/Entrepreneurialecosystems-OECD.pdf.

McGowan, P., Cooper, S. and Van der Sijde, P. (2011), “Entrepreneurship and high-technology ventures”, International Journal of Entrepreneurial Behavior \& Research, Vol. 17 No. 6.

MEIC (2010), Política pública: Costa Rica Emprende. Ministerio de Economía Industria y Comercio. Costa Rica. 
MEIC (2014), Política pública: Fomento al Emprendimiento. Ministerio de Economía Industria y Comercio. Costa Rica.

MEIC (2019), Estado del Ecosistema Empresarial 2019. Ministerio de Economía Industria y Comercio. Costa Rica.

Melyn, W. and Moesen, W. (1991), "Towards a synthetic indicator of macroeconomic performance: unequal weighting when limited information is available”, Public Economic Research Paper 17, CES, KU Leuven.

Mizobuchi, H. (2014), "Measuring world better life frontier: A composite indicator for OECD better life index”, Social Indicators Research, Vol. 118, pp. 987-1007.

Moore, J. (1993), “Predators and Prey: A New Ecology of Competition”, Harvard Business Review, Vol. 71 No. 3, pp. 75-86.

MWC (2019), “Startup Ecosystem Overview 2019”, available at: https://mobileworldcapital.com/es/report/startup-ecosystem-overview-2019/\#slide4 (last retrieved 30 April 2020).

Newbert, S. (2007), "Empirical research on the Resource-based view of the firm: An assessment and suggestions for future research”, Strategic Management Journal, Vol. 28 No. 2, pp. 121146.

Nunnally, J.C. and Bernstein, I.H. (1994), Psychometric theory. McGraw-Hill.

O’Cass, A. and Weerawardena, J. (2010), “The effects of perceived industry competitive intensity and marketing-related capabilities: drivers of superior brand performance”, Industrial Marketing Management, Vol. 39 No. 4, pp. 571-581.

Organization for Economic Cooperation and Development (OECD) (2008), Handbook on constructing composite indicators: Methodology and user guide. Paris: OECD Publishing. ISBN 978-92-64-04345-9.

Organization for Economic Cooperation and Development (OECD) (2016), Entrepreneurship at a glance 2016. Paris: OECD Publishing. doi: http://dx.doi.org/10.1787/entrepreneur_aag-2016-en

Organization for Economic Cooperation and Development (OECD) (2019), OECD SME and Entrepreneurship Outlook 2019. Paris: OECD Publishing. doi: https://doi.org/10.1787/34907e9c-en

Organization for Economic Cooperation and Development (OECD) (2020), OECD Economic Surveys: Costa Rica 2020. Paris: OECD Publishing. doi: https://doi.org/10.1787/2e0fea6c-en

Parzen, E. (1962), “Estimation of a probability density-function and mode”, Annals of Mathematical Statistics, Vol. 33, pp. 1065-1076. 
Patton, D. and Kenney, M. (2005), “The spatial configuration of the entrepreneurial support network for the semiconductor industry”, R\&D Management, Vol. 35 No. 1, pp. 1-17.

Peña-Legazkue, I., Guerrero, M., González-Pernía, J.L. and Montero, J. (2019), Global Entrepreneurship Monitor. Informe GEM España 2018-2019(Vol. 244). Ed. Universidad de Cantabria.

Rabetino, R., Harmsen, W., Kohtamäki, M. and Sihvonen, J. (2018), "Structuring servitizationrelated research”, International Journal of Operations \& Production Management, Vol. 38 No. 2, pp. 350-371.

Rosenblatt, M. (1956), “Estimation of a probability density-function and mode”, Annals of Mathematical Statistics, Vol. 27, pp. 832-837.

Sahoo, B.K., Singh, R., Mishra, B. and Sankaran, K. (2017), "Research productivity in management schools of India during 1968-2015: A directional benefit-of-doubt model analysis”, Omega, Vol. 66, pp. 118-139.

Silverman, B.W. (1986), Density estimation for statistics and data analysis, London, Chapman and Hall.

Sirmon, D.G., Hitt, M.A., Arregle, J.L. and Campbell, J.T. (2010), “The dynamic interplay of capability strengths and weaknesses: investigating the bases of temporary competitive advantage”, Strategic Management Journal, Vol. 31 No. 13, pp. 1386-1409.

Snijders, T.A.B. and Bosker, R.J. (2012), Multilevel analysis: an introduction to basic and advanced multilevel modeling, 2nd ed., Los Angeles (CA), Sage.

Spigel, B. (2017), “The relational organization of entrepreneurial ecosystems”, Entrepreneurship Theory and Practice, Vol. 41 No. 1, pp. 49-72.

Spigel, B. and Harrison, R. (2018), “Toward a process theory of entrepreneurial ecosystems”, Strategic Entrepreneurship Journal, Vol. 12 No. 1, pp. 151-168.

Stam, E. (2015), "Entrepreneurial ecosystems and regional policy: a sympathetic critique”, European Planning Studies, Vol. 23 No. 9, pp. 1759-1769.

Stam, E. and van de Ven, A. (2021). "Entrepreneurial ecosystem elements”, Small Business Economics, Vol. 56, pp. 809-832.

Szerb, L., Komlósi, É. and Páger, B. (2017), “A multidimensional, comparative analysis of the regional entrepreneurship performance in the Central and Eastern European EU member countries”. In Sauka, A. and Chepurenko, A., Entrepreneurship in Transition Economies (pp. 35-56). Springer, ISBN 978-3-319-57341-0.

Tarabusi, E.C. and Guarini, G. (2013), “An unbalance adjustment method for development indicators”, Social Indicators Research, Vol. 112 No. 1, pp. 19-45. 
Tippins, M.J. and Sohi, R.S. (2003), "IT competency and firm performance: is organizational learning a missing link?”, Strategic Management Journal, Vol. 24 No. 8, pp. 745-761.

van de Ven, H. (1993), “The development of an infrastructure for entrepreneurship”, Journal of Business Venturing, Vol. 8 No. 3, pp. 211-230.

Vendrell-Herrero, F., Bustinza, O.F., Parry, G. and Georgantzis, N. (2017), “Servitization, digitization and supply chain interdependency”, Industrial Marketing Management, Vol. 60, pp. 69-81.

Wernerfelt, B. (1984), “A Resource-Based View of the Firm”, Strategic Management Journal, Vol. 5 No. 2, pp. 171-180.

Wurth, B., Stam, E., and Spigel, B. (2021), “Toward an Entrepreneurial Ecosystem Research Program”, Entrepreneurship Theory and Practice, in press, doi: 10. 1177/ 1042258721998948.

Wyrwich, M. (2019), "New KIBS on the bloc: the role of local manufacturing for start-up activity in knowledge-intensive business services”, Regional Studies, Vol. 53 No. 3, pp. 320-329. 


\section{List of tables}

Table 1. Descriptive statistics for the study variables

\begin{tabular}{|c|c|c|c|c|c|c|c|c|c|c|}
\hline & \multicolumn{2}{|c|}{ Full sample } & \multicolumn{2}{|c|}{ France } & \multicolumn{2}{|c|}{ Spain } & \multicolumn{2}{|c|}{ Costa Rica } & \multicolumn{2}{|c|}{ Hungary } \\
\hline & $\begin{array}{c}\text { Mean } \\
\text { (Std. dev.) }\end{array}$ & Obs. & $\begin{array}{c}\text { Mean } \\
\text { (Std. dev.) }\end{array}$ & Obs. & $\begin{array}{c}\text { Mean } \\
\text { (Std. dev.) }\end{array}$ & Obs. & $\begin{array}{c}\text { Mean } \\
\text { (Std. dev.) }\end{array}$ & Obs. & $\begin{array}{c}\text { Mean } \\
\text { (Std. dev.) }\end{array}$ & Obs. \\
\hline \multicolumn{11}{|l|}{ Panel A: Competitiveness } \\
\hline Competitiveness index & $4.90(1.45)$ & 348 & $5.12(1.60)$ & 83 & $5.20(1.46)$ & 92 & $4.71(1.30)$ & 79 & $4.58(1.34)$ & 94 \\
\hline Human capital & $0.49(0.17)$ & 348 & $0.51(0.22)$ & 83 & $0.51(0.12)$ & 92 & $0.47(0.16)$ & 79 & $0.46(0.17)$ & 94 \\
\hline Domestic market & $0.49(0.16)$ & 348 & $0.50(0.15)$ & 83 & $0.53(0.18)$ & 92 & $0.50(0.13)$ & 79 & $0.45(0.16)$ & 94 \\
\hline Internationalization & $0.48(0.19)$ & 348 & $0.52(0.21)$ & 83 & $0.50(0.19)$ & 92 & $0.48(0.17)$ & 79 & $0.44(0.18)$ & 94 \\
\hline Product innovation & $0.50(0.20)$ & 348 & $0.52(0.20)$ & 83 & $0.53(0.21)$ & 92 & $0.49(0.22)$ & 79 & $0.46(0.18)$ & 94 \\
\hline Technology & $0.49(0.16)$ & 348 & $0.51(0.17)$ & 83 & $0.52(0.16)$ & 92 & $0.48(0.14)$ & 79 & $0.46(0.16)$ & 94 \\
\hline Networks & $0.49(0.19)$ & 348 & $0.52(0.20)$ & 83 & $0.51(0.18)$ & 92 & $0.48(0.18)$ & 79 & $0.45(0.20)$ & 94 \\
\hline Marketing & $0.49(0.18)$ & 348 & $0.51(0.18)$ & 83 & $0.53(0.19)$ & 92 & $0.45(0.18)$ & 79 & $0.47(0.15)$ & 94 \\
\hline Online presence & $0.48(0.25)$ & 348 & $0.50(0.21)$ & 83 & $0.52(0.27)$ & 92 & $0.44(0.25)$ & 79 & $0.46(0.25)$ & 94 \\
\hline Decision making & $0.49(0.20)$ & 348 & $0.53(0.22)$ & 83 & $0.53(0.21)$ & 92 & $0.47(0.21)$ & 79 & $0.45(0.17)$ & 94 \\
\hline Competitive strategy & $0.49(0.18)$ & 348 & $0.51(0.17)$ & 83 & $0.53(0.17)$ & 92 & $0.45(0.17)$ & 79 & $0.47(0.19)$ & 94 \\
\hline \multicolumn{11}{|l|}{ Panel B: Firm profile } \\
\hline Business size (employees) & $\begin{array}{c}54.88 \\
(144.19)\end{array}$ & 348 & $\begin{array}{c}95.14 \\
(219.09)\end{array}$ & 83 & $\begin{array}{c}45.92 \\
(122.23)\end{array}$ & 92 & $\begin{array}{c}61.19 \\
(127.43)\end{array}$ & 79 & $\begin{array}{c}16.01 \\
(19.50)\end{array}$ & 94 \\
\hline Business age (years) & $\begin{array}{c}16.15 \\
(11.70)\end{array}$ & 348 & $\begin{array}{l}12.38 \\
(6.27) \\
\end{array}$ & 83 & $\begin{array}{c}17.51 \\
(15.37)\end{array}$ & 92 & $\begin{array}{c}18.40 \\
(13.85) \\
\end{array}$ & 79 & $\begin{array}{l}16.28 \\
(8.08) \\
\end{array}$ & 94 \\
\hline \multicolumn{11}{|l|}{$\begin{array}{l}\text { Panel C: Entrepreneurial } \\
\text { ecosystem }\end{array}$} \\
\hline GEI index in 2018 & 45.71 & 348 & 68.50 & 83 & 45.30 & 92 & 33.30 & 79 & 36.40 & 94 \\
\hline
\end{tabular}

Note: Standard deviation is presented in parentheses. 
Table 2. Benefit of the doubt (BOD) model: Output set

\begin{tabular}{|c|c|c|c|c|}
\hline & $\begin{array}{l}\text { y1: } \\
\text { Human capital }\end{array}$ & $\begin{array}{l}\text { y2: } \\
\text { Markets }\end{array}$ & $\begin{array}{l}\text { y3: } \\
\text { Innovation }\end{array}$ & $\begin{array}{l}\mathbf{y 4 :} \\
\text { Strategy }\end{array}$ \\
\hline Panel A: France $(\mathrm{N}=83)$ & $0.52(0.22)$ & $1.01(0.33)$ & $1.03(0.37)$ & $2.57(0.78)$ \\
\hline Manufacturing $(\mathrm{N}=53)$ & $0.46(0.20)$ & $0.92(0.31)$ & $0.90(0.33)$ & $2.31(0.71)$ \\
\hline KIBS $(\mathrm{N}=30)$ & $0.60(0.22)$ & $1.18(0.32)$ & $1.24(0.34)$ & $3.03(0.67)$ \\
\hline Panel B: Spain $(\mathrm{N}=92)$ & $0.51(0.12)$ & $1.03(0.34)$ & $1.04(0.34)$ & $2.62(0.82)$ \\
\hline Manufacturing $(\mathrm{N}=52)$ & $0.52(0.12)$ & $1.04(0.38)$ & $0.99(0.37)$ & $2.64(0.90)$ \\
\hline KIBS $(\mathrm{N}=40)$ & $0.50(0.11)$ & $1.02(0.30)$ & $1.11(0.28)$ & $2.60(0.73)$ \\
\hline Panel C: Costa Rica $(\mathrm{N}=79)$ & $0.47(0.16)$ & $0.98(0.25)$ & $0.98(0.33)$ & $2.29(0.74)$ \\
\hline Manufacturing $(\mathrm{N}=47)$ & $0.45(0.17)$ & $0.97(0.26)$ & $0.96(0.33)$ & $2.18(0.74)$ \\
\hline KIBS $(\mathrm{N}=32)$ & $0.49(0.16)$ & $0.99(0.25)$ & $1.00(0.34)$ & $2.44(0.73)$ \\
\hline Panel D: Hungary $(\mathrm{N}=94)$ & $0.46(0.17)$ & $0.90(0.31)$ & $0.92(0.31)$ & $2.30(0.73)$ \\
\hline Manufacturing $(\mathrm{N}=62)$ & $0.44(0.17)$ & $0.89(0.28)$ & $0.93(0.29)$ & $2.33(0.73)$ \\
\hline KIBS (N= 32) & $0.51(0.17)$ & $0.92(0.36)$ & $0.91(0.33)$ & $2.25(0.75)$ \\
\hline
\end{tabular}

Note: KIBS refers to knowledge intensive business services firms. Standard deviation is presented in parentheses.

Table 3. Benefit of the doubt (BOD) model: Summary results

\begin{tabular}{l|c|c|c|c|c}
\hline & Full Sample & France & Spain & Costa Rica & Hungary \\
\hline Panel A: Overall & & & & & \\
\hline CI score (BOD model) & $\begin{array}{c}0.6162 \\
(0.1944)\end{array}$ & $\begin{array}{c}0.6121 \\
(0.2152)\end{array}$ & $\begin{array}{c}0.6512 \\
(0.1860)\end{array}$ & $\begin{array}{c}0.6257 \\
(0.1777)\end{array}$ & $\begin{array}{c}0.5777 \\
(0.1925)\end{array}$ \\
\hline Observations & 348 & 83 & 92 & 79 & 94 \\
\hline Panel B: Manufacturing & & & & & \\
\hline CI score (BOD model) & 0.5751 & 0.5362 & 0.6074 & 0.6259 & 0.5427 \\
& $(0.1841)$ & $(0.1831)$ & $(0.1892)$ & $(0.1879)$ & $(0.1673)$ \\
\hline Observations & 214 & 53 & 52 & 47 & 62 \\
\hline Panel C: KIBS & & & & & \\
\hline CI score (BOD model) & 0.6820 & 0.7462 & 0.7081 & 0.6254 & 0.6456 \\
& $(0.1930)$ & $(0.2042)$ & $(0.1676)$ & $(0.1644)$ & $(0.2212)$ \\
\hline Observations & 134 & 30 & 40 & 32 & 32 \\
\hline
\end{tabular}

Note: Standard deviation is presented in parentheses. 
Table 4. Multilevel model: Regression results

\begin{tabular}{l|c|c}
\hline Variables & Model 1: Baseline model & Model 2: Full model \\
\hline Intercept & $0.6165(0.0157)^{* * *}$ & $0.4601(0.0375)^{* * *}$ \\
\hline Firm size (ln employees) & & $0.0706(0.0062)^{* * *}$ \\
\hline Firm age (ln years) & & $-0.0267(0.0127)^{* *}$ \\
\hline KIBS (dummy) & & $0.0852(0.0178)^{* * *}$ \\
\hline Random effects & & \\
\hline Country intercept variance (GEI index) & $0.0096(0.0011)^{* * *}$ & $0.0085(0.0043)^{* *}$ \\
\hline Residual variance & $0.0374(0.0028)^{* * *}$ & $0.0254(0.0020)^{* * *}$ \\
\hline Log likelihood & 73.7565 & 130.6593 \\
\hline Wald test (chi $\left.{ }^{2}\right)$ & --- & $164.08^{* * *}$ \\
\hline Pseudo R2 (McFadden) & --- & 0.4355 \\
\hline LR test vs. linear regression & $2.65^{* *}$ & $6.73^{* * *}$ \\
\hline Number of observations & 348 & 348 \\
\hline
\end{tabular}

Dependent variable: BOD scores $\left(C I_{i}^{B O D}\right)$ computed by solving the linear program presented in equation (2). All variables are at business level (level 2) except the GEI index (level 1). Standard error is presented in parentheses. $*, * *, * * *$ indicate significance at the $10 \%, 5 \%$ and $1 \%$, respectively. 
Table 5. Benefit of the doubt (BOD) model: Competitive efficiency and prioritization of strategic variables (endogenous weight)

\begin{tabular}{|c|c|c|c|c|c|c|c|c|c|c|c|c|}
\hline & \multicolumn{3}{|c|}{ France } & \multicolumn{3}{|c|}{ Spain } & \multicolumn{3}{|c|}{ Costa Rica } & \multicolumn{3}{|c|}{ Hungary } \\
\hline & Overall & Manuf. & KIBS & Overall & Manuf. & KIBS & Overall & Manuf. & KIBS & Overall & Manuf. & KIBS \\
\hline \multicolumn{13}{|l|}{ Panel A: Full sample } \\
\hline BOD score & 0.6121 & 0.5362 & 0.7462 & 0.6512 & 0.6074 & 0.7081 & 0.6257 & 0.6259 & 0.6254 & 0.5777 & 0.5427 & 0.6456 \\
\hline Weight y1: Human capital & 0.4669 & 0.4667 & 0.4623 & 0.4512 & 0.4387 & 0.4652 & 0.4662 & 0.4722 & 0.4568 & 0.4562 & 0.4760 & 0.4210 \\
\hline Weight y2: Markets & 0.2230 & 0.2261 & 0.2327 & 0.2325 & 0.2355 & 0.2299 & 0.2164 & 0.2135 & 0.2211 & 0.2343 & 0.2268 & 0.2607 \\
\hline Weight y3: Innovation & 0.2232 & 0.2205 & 0.2177 & 0.2265 & 0.2092 & 0.2419 & 0.2241 & 0.2189 & 0.2328 & 0.2218 & 0.2127 & 0.2120 \\
\hline Weight y4: Strategy & 0.0870 & 0.0867 & 0.0874 & 0.0898 & 0.0896 & 0.0900 & 0.0933 & 0.0954 & 0.0903 & 0.0877 & 0.0845 & 0.1063 \\
\hline \multicolumn{13}{|l|}{ Panel B: Upper quartile } \\
\hline BOD score & 0.9052 & 0.9048 & 0.9054 & 0.8550 & 0.8617 & 0.8561 & 0.8675 & 0.8546 & 0.8976 & 0.8113 & 0.7601 & 0.9074 \\
\hline Weight y1: Human capital & 0.4321 & 0.4191 & 0.4371 & 0.4566 & 0.4448 & 0.4592 & 0.4572 & 0.4603 & 0.4491 & 0.4366 & 0.4445 & 0.4362 \\
\hline Weight y2: Markets & 0.2318 & 0.2450 & 0.2267 & 0.2060 & 0.2106 & 0.2034 & 0.2277 & 0.2261 & 0.2314 & 0.2415 & 0.2444 & 0.2497 \\
\hline Weight y3: Innovation & 0.2417 & 0.2206 & 0.2621 & 0.2553 & 0.2464 & 0.2605 & 0.2233 & 0.2212 & 0.2288 & 0.2320 & 0.2229 & 0.2214 \\
\hline Weight y4: Strategy & 0944 & 0.0953 & 0.0941 & 0.0821 & 0.0941 & 0.0810 & 0.0918 & 0.0924 & 0.0907 & 0.0899 & 0.0882 & 0.0927 \\
\hline \multicolumn{13}{|l|}{ Panel C: Bottom quartile } \\
\hline BOD score & 0.3757 & 0.3755 & 0.3775 & 0.3816 & 0.3856 & 0.3672 & 0.4060 & 0.3966 & 0.4221 & 0.3359 & 0.3321 & 0.3431 \\
\hline Weight y1: Human capital & 0.5000 & 0.4976 & 0.5212 & 0.3961 & 0.3700 & 0.3774 & 0.4716 & 0.4818 & 0.4530 & 0.4755 & 0.5220 & 0.3931 \\
\hline Weight y2: Markets & 0.2214 & 0.2191 & 0.2422 & 0.2881 & 0.2587 & 0.3070 & 0.2359 & 0.2231 & 0.2594 & 0.2456 & 0.2162 & 0.2979 \\
\hline Weight y3: Innovation & 0.2045 & 0.2082 & 0.1710 & 0.2233 & 0.2686 & 0.2152 & 0.2024 & 0.2039 & 0.1995 & 0.1990 & 0.1821 & 0.2289 \\
\hline Weight y4: Strategy & 0.0741 & 0.0751 & 0.0655 & 0.0925 & 0.1027 & 0.1004 & 0.0901 & 0.0912 & 0.0881 & 0.0799 & 0.0798 & 0.0802 \\
\hline Cases & 83 & 53 & 30 & 92 & 52 & 40 & 79 & 47 & 32 & 94 & 62 & 32 \\
\hline
\end{tabular}

Note: The column 'Manuf.' shows the results for manufacturing businesses, whereas the column 'KIBS' presents the findings for knowledge intensive business services firms. 


\section{Appendix}

Appendix 1. Main characteristics of the entrepreneurial context among the select countries

\begin{tabular}{|c|c|c|c|c|}
\hline & France & Spain & Costa Rica & Hungary \\
\hline Sources & $\begin{array}{l}\text { European Commission } \\
\text { (2018a, 2019) } \\
\text { OECD (2019) }\end{array}$ & $\begin{array}{l}\text { European Commission } \\
\text { (2018a, 2019) } \\
\text { OECD (2019) }\end{array}$ & $\begin{array}{l}\text { MEIC }(2010,2014,2019) \\
\operatorname{OECD}(2020)\end{array}$ & $\begin{array}{l}\text { European Commission } \\
\text { (2018a, 2019) } \\
\text { OECD (2019) }\end{array}$ \\
\hline $\begin{array}{l}\text { Institutional } \\
\text { and } \\
\text { regulatory } \\
\text { framework }\end{array}$ & $\begin{array}{l}\text { Strong institutions and low } \\
\text { costs for new ventures } \\
\text { support entrepreneurship. } \\
\text { However, administrative } \\
\text { burdens and procedures limit } \\
\text { entrepreneurship in some } \\
\text { industries. }\end{array}$ & $\begin{array}{l}\text { Similar to most OEDC } \\
\text { countries. } \\
\text { regulatory differences across } \\
\text { Spanish regions create costs } \\
\text { and barriers to SME that limit } \\
\text { this expansion within Spain. }\end{array}$ & $\begin{array}{l}\text { Various policies have been } \\
\text { introduced to support } \\
\text { entrepreneurship actions since } \\
2010.6 \\
\text { Also, } 79 \text { institutions are part } \\
\text { of the SME Support Network } \\
\text { and the National Network of } \\
\text { Incubators and Accelerators. }\end{array}$ & $\begin{array}{l}\text { Developing institutions which } \\
\text { are complemented by } \\
\text { entrepreneurship programs } \\
\text { sponsored by the EU. } \\
\text { The low level of digitalization } \\
\text { of public services (compared } \\
\text { to other OECD countries) } \\
\text { constrains start-up processes. }\end{array}$ \\
\hline $\begin{array}{l}\text { Market } \\
\text { conditions }\end{array}$ & $\begin{array}{l}\text { Homogeneous conditions } \\
\text { consolidate the exploitation of } \\
\text { business opportunities at the } \\
\text { national level (including } \\
\text { public contracts). Also, the } \\
\text { easy access to a consolidated } \\
\text { support network facilitates } \\
\text { SMEs'internationalization. }\end{array}$ & $\begin{array}{l}\text { The proportion of Spanish } \\
\text { exporting SMEs has } \\
\text { increased, but the rate of } \\
\text { exporting SMEs is still low } \\
\text { compared to OECD figures. } \\
\text { At the national level, both the } \\
\text { requirements and the payment } \\
\text { periods for SMEs have been } \\
\text { reduced which facilitates } \\
\text { access to local markets and } \\
\text { public contracts. }\end{array}$ & $\begin{array}{l}\text { In public procurement process } \\
\text { area, there are ongoing } \\
\text { initiatives for SMEs and } \\
\text { young entrepreneurs to } \\
\text { participate in a sustainable } \\
\text { way in public bidding } \\
\text { processes. Concerning SMEs' } \\
\text { internationalization, the value } \\
\text { of exports showed a } \\
\text { downward trend between } \\
2012 \text { and } 2017 \text {. }\end{array}$ & $\begin{array}{l}\text { The integration of Hungarian } \\
\text { companies in global value } \\
\text { chains has been achieved in } \\
\text { sectors such as automotive. } \\
\text { However, market prospects } \\
\text { show an overall low } \\
\text { participation in global } \\
\text { markets. }\end{array}$ \\
\hline
\end{tabular}

\footnotetext{
${ }^{6}$ The National Entrepreneurship Policy ('Costa Rica Emprende’) in 2010 and Costa Rica Entrepreneurship Promotion (2014) (MEIC, 2014).

${ }^{7}$ The report included 58 actors: 50\% public agencies, 47\% private agencies, and 3\% mixed agencies (public-private collaborations). The activities carried out by each agency are grouped into two main areas: a) business life cycle (entrepreneurial culture, pre start-up and start-up processes, development-growth and maturity) and (b) categories/activities within ecosystem (support policies, access to financial resources, innovation and markets) (MEIC, 2019).
} 
Appendix 1. Continued.

\begin{tabular}{|c|c|c|c|c|}
\hline & France & Spain & Costa Rica & Hungary \\
\hline Sources & $\begin{array}{l}\text { European Commission } \\
(2018 a, 2019) \\
\text { OECD (2019) } \\
\end{array}$ & $\begin{array}{l}\text { European Commission } \\
\text { (2018a, 2019) } \\
\text { OECD (2019) }\end{array}$ & $\begin{array}{l}\text { MEIC }(2010,2014,2019) \\
\text { OECD }(2020)\end{array}$ & $\begin{array}{l}\text { European Commission } \\
(2018 a, 2019) \\
\text { OECD (2019) }\end{array}$ \\
\hline Infrastructure & $\begin{array}{l}\text { Transport and energy } \\
\text { infrastructure are atop the } \\
\text { OECD. } \\
\text { High level of digital } \\
\text { investments (ICT and } \\
\text { broadband) that cover the } \\
\text { entire country. } \\
\text { The research infrastructure } \\
\text { coexists between weak } \\
\text { international and industry- } \\
\text { science networks and strong } \\
\text { inter-regional networks }\end{array}$ & $\begin{array}{l}\text { A high-quality system of } \\
\text { physical infrastructures which } \\
\text { facilitates communications } \\
\text { (transportation) between } \\
\text { regions. } \\
\text { Compared to OECD figures, } \\
\text { the country reports an average } \\
\text { level of digital infrastructures } \\
\text { as well as fixed and mobile } \\
\text { broadband penetration. }\end{array}$ & $\begin{array}{l}\text { Important bottlenecks exist, } \\
\text { especially due to the low } \\
\text { quality level of the road } \\
\text { transport network, which } \\
\text { affects economic activity and } \\
\text { regional development. } \\
\text { The country reports a good, } \\
\text { developing level of digital } \\
\text { infrastructures. }\end{array}$ & $\begin{array}{l}\text { Compared to OECD levels, } \\
\text { ICT investments and mobile } \\
\text { broadband penetration are } \\
\text { low. } \\
\text { Also, the rail and road } \\
\text { infrastructure must be } \\
\text { renewed and requires heavy } \\
\text { investment. }\end{array}$ \\
\hline $\begin{array}{l}\text { Acc } \\
\text { fina }\end{array}$ & $\begin{array}{l}\text { Strong banking system with } \\
\text { the capacity to offer flexible } \\
\text { credit conditions to SMEs. }\end{array}$ & $\begin{array}{l}\text { In recent years interest rates } \\
\text { and spreads have decreased. } \\
\text { Furthermore, reduced credit } \\
\text { conditions have benefited the } \\
\text { access to finance by SMEs } \\
\text { and entrepreneurs. }\end{array}$ & $\begin{array}{l}\text { Credit conditions complicate } \\
\text { access to finance to SMEs } \\
\text { and entrepreneurs. At the } \\
\text { same time, Costa Rican SMEs } \\
\text { pay higher interest rates } \\
\text { compared to large companies. }\end{array}$ & $\begin{array}{l}\text { Credit to SMEs mostly covers } \\
\text { short-term, highly volatile } \\
\text { operations. } \\
\text { Also, the overall perceived } \\
\text { trust level in the credit market } \\
\text { is low among businesses. }\end{array}$ \\
\hline $\begin{array}{l}\text { Access to } \\
\text { skills }\end{array}$ & $\begin{array}{l}\text { Educated population with } \\
\text { entrepreneurial intentions. } \\
\text { Unemployment rate is } \\
\text { relatively high (around 9\%), } \\
\text { and training for workers is an } \\
\text { area that could be } \\
\text { strengthened. }\end{array}$ & $\begin{array}{l}\text { Polarized demand of workers' } \\
\text { skills (between positions } \\
\text { requiring high or low } \\
\text { qualifications). } \\
\text { On-the-job training is below } \\
\text { OECD standards. }\end{array}$ & $\begin{array}{l}\text { Recent policies seek to } \\
\text { narrow the gap between low- } \\
\text { and high-qualified workers. } \\
\text { Also, 41 agencies provide } \\
\text { support services (e.g., } \\
\text { training, technical assistance, } \\
\text { infrastructure) to businesses } \\
\text { at different stages of their life } \\
\text { cycle. }\end{array}$ & $\begin{array}{l}\text { Improvements in access to } \\
\text { knowledge and training are } \\
\text { evident during the last } \\
\text { decade. } \\
\text { However, the level of } \\
\text { workforce training is below } \\
\text { OECD standards }\end{array}$ \\
\hline
\end{tabular}


Appendix 1. Continued.

\begin{tabular}{|c|c|c|c|c|}
\hline & France & Spain & Costa Rica & Hungary \\
\hline Sources & $\begin{array}{l}\text { European Commission } \\
\text { (2018a, 2019) } \\
\text { OECD (2019) }\end{array}$ & $\begin{array}{l}\text { European Commission } \\
\text { (2018a, 2019) } \\
\text { OECD (2019) }\end{array}$ & $\begin{array}{l}\text { MEIC }(2010,2014,2019) \\
\text { OECD (2020) }\end{array}$ & $\begin{array}{l}\text { European Commission } \\
\text { (2018a, 2019) } \\
\text { OECD (2019) }\end{array}$ \\
\hline $\begin{array}{l}\text { Access to } \\
\text { innovation } \\
\text { assets }\end{array}$ & $\begin{array}{l}\text { High participation of SMEs in } \\
\text { innovation projects. } \\
\text { However, technology } \\
\text { improvements are needed in } \\
\text { order to enhance the activity } \\
\text { of industries that heavily rely } \\
\text { on ICTs, such as cloud } \\
\text { computing services. }\end{array}$ & $\begin{array}{l}\text { SMEs invest less in ICT } \\
\text { equipment than their OECD } \\
\text { counterparts, but they are } \\
\text { proactive in adopting high- } \\
\text { speed broadband. } \\
\text { SMEs are less involved in } \\
\text { innovation activities, but their } \\
\text { digital practices are similar to } \\
\text { OECD average levels. }\end{array}$ & $\begin{array}{l}\text { Country characterized by a } \\
\text { dual economy, combining an } \\
\text { innovative and dynamic } \\
\text { export sector with local SMEs } \\
\text { that do not benefit from the } \\
\text { global economy (non- } \\
\text { exporters without presence in } \\
\text { global value chains). } \\
\text { Furthermore, the interaction } \\
\text { between public universities } \\
\text { and the local business fabric } \\
\text { is a major weakness. }\end{array}$ & $\begin{array}{l}\text { The participation of } \\
\text { Hungarian SMEs in R\&D and } \\
\text { networks is similar to OECD } \\
\text { median level. Nevertheless, } \\
\text { few Hungarian SMEs } \\
\text { innovate. }\end{array}$ \\
\hline
\end{tabular}


Appendix 2. GEI Indicators: Results for 2018

\begin{tabular}{l|c|c|c|c}
\hline \multicolumn{1}{c|}{ GEI Indicator } & France & Spain & Costa Rica & Hungary \\
\hline Startup Skills (R) & 0.451 & 0.682 & 0.723 & 0.327 \\
\hline Human Capital (R) & 0.549 & 0.395 & 0.218 & 0.476 \\
\hline Product Innovation (R) & 0.650 & 0.317 & 0.275 & 0.253 \\
\hline Process Innovation (R) & 0.891 & 0.551 & 0.309 & 0.441 \\
\hline High Growth (R) & 0.590 & 0.269 & 0.283 & 0.481 \\
\hline Internationalization (R) & 0.721 & 0.364 & 0.222 & 0.495 \\
\hline Risk Capital (R) & 0.747 & 0.557 & 0.185 & 0.316 \\
\hline Technology Absorption (N) & 0.941 & 0.750 & 0.176 & 0.495 \\
\hline Risk Acceptance (N) & 0.680 & 0.663 & 0.326 & 0.168 \\
\hline Networking (N) & 0.649 & 0.624 & 0.377 & 0.362 \\
\hline Opportunity Startup (N) & 0.941 & 0.544 & 0.341 & 0.562 \\
\hline Competition (N) & 0.758 & 0.408 & 0.346 & 0.302 \\
\hline Opportunity Perception (N) & 0.469 & 0.394 & 0.411 & 0.316 \\
\hline Cultural Support (N) & 0.646 & 0.333 & 0.462 & 0.342 \\
\hline Soure: Glob2
\end{tabular}

Source: Global Entrepreneurship Index data base 2018. $\mathrm{R}=$ resources, $\mathrm{N}=$ networks. 
Appendix 3. Variables used to estimate the business competitiveness index, according to pillar and aggregate pillar

\begin{tabular}{|c|c|c|}
\hline $\begin{array}{l}\text { Competitive pillars } \\
\text { (related literature) }\end{array}$ & Variables included in each pillar & Scale \\
\hline \multicolumn{3}{|l|}{ 1. Innovation } \\
\hline $\begin{array}{l}\text { 1.1 Product innovation } \\
\text { (Hansen et al., } 2013 \\
\text { Lafuente et al., 2018) }\end{array}$ & $\begin{array}{l}\text { The introduction of new or amended products } \\
\text { The share of new product in sales } \\
\text { The uniqueness of firm's product and continuous innovation }\end{array}$ & $\begin{array}{l}0=\text { no relevance } / 4=\text { high relevance } \\
\text { Value in } \% \\
0=\text { no relevance } / 4=\text { high relevance }\end{array}$ \\
\hline $\begin{array}{l}1.2 \text { Technology } \\
\text { (Cusumano et al., 2015; } \\
\text { Douglas and Ryman, 2003) }\end{array}$ & $\begin{array}{l}\text { The level of firm's technology } \\
\text { The age of available technology used by the firm and technological innovation } \\
\text { Environmental investment and quality assurance } \\
\text { The level of application of ICT tools } \\
\text { Uniqueness of applied technology, possession of license or know-how, } \\
\text { product management and quality assurance }\end{array}$ & $\begin{array}{l}0=\text { no relevance } / 4=\text { high relevance } \\
0=\text { no relevance } / 4=\text { high relevance } \\
0=\text { no relevance } / 4=\text { high relevance } \\
0=\text { no relevance } / 4=\text { high relevance } \\
0=\text { no relevance } / 4=\text { high relevance }\end{array}$ \\
\hline \multicolumn{3}{|l|}{ 2. Markets } \\
\hline $\begin{array}{l}\text { 2.1 Domestic market } \\
\text { (Julien and Ramangalahy, 2003; } \\
\text { Ketchen et al., 2007) }\end{array}$ & $\begin{array}{l}\text { The geographic scope of selling } \\
\text { The level of firm's competition in the market } \\
\text { The expected growth of the target market in five years } \\
\text { The intensity of competition } \\
\text { Quick response to costumers' demand }\end{array}$ & $\begin{array}{l}0=\text { no relevance } / 4=\text { high relevance } \\
0=\text { no relevance } / 4=\text { high relevance } \\
0=\text { no relevance } / 4=\text { high relevance } \\
0=\text { no relevance } / 4=\text { high relevance } \\
0=\text { no relevance } / 4=\text { high relevance }\end{array}$ \\
\hline $\begin{array}{l}2.2 \text { Internationalization } \\
\text { (Belderbos and Sleuwaegen, 2005; } \\
\text { Julien and Ramangalahy, 2003) }\end{array}$ & $\begin{array}{l}\text { The significance of foreign buyers } \\
\text { The share of export in sales } \\
\text { Language capabilities at business level } \\
\text { The uniqueness of location }\end{array}$ & $\begin{array}{l}0=\text { no relevance } / 4=\text { high relevance } \\
\text { Value in } \% \\
0=\text { no relevance } / 4=\text { high relevance } \\
0=\text { no relevance } / 4=\text { high relevance } \\
\end{array}$ \\
\hline \multicolumn{3}{|l|}{ 3. Human Capital } \\
\hline $\begin{array}{l}\text { 3.1 Human capital } \\
\text { (Aral and Weill, 2007; } \\
\text { Lafuente and Rabetino, 2011) }\end{array}$ & $\begin{array}{l}\text { The number and share of employees with higher education degree } \\
\text { The problems with employees } \\
\text { The share of employees participating in training programs } \\
\text { The sophistication of compensation systems } \\
\text { The uniqueness of human capital }\end{array}$ & $\begin{array}{l}\text { Numerical value / value in } \% \\
0=\text { no relevance / } 4=\text { high relevance } \\
\text { Value in } \% \\
0=\text { no relevance } / 4=\text { high relevance } \\
0=\text { no relevance } / 4=\text { high relevance }\end{array}$ \\
\hline
\end{tabular}


Appendix 3. Continued.

\begin{tabular}{|c|c|c|}
\hline $\begin{array}{l}\text { Competitive pillars } \\
\text { (related literature) }\end{array}$ & Variables included in each pillar & Scale \\
\hline \multicolumn{3}{|l|}{ 4.Strategy } \\
\hline $\begin{array}{l}4.1 \text { Networks } \\
\text { (Alonso-Ubieta and Leiva, 2019; } \\
\text { Kingsley and Malecki, 2004; } \\
\text { Patton and Kenney, 2005) } \\
\end{array}$ & $\begin{array}{l}\text { The number of economic cooperation and innovation agreements } \\
\text { The time of networking as compared to the establishment of the firm } \\
\text { The reliance to outside help in business development } \\
\text { Uniqueness of networking relationship. }\end{array}$ & \begin{tabular}{|l} 
Numerical value \\
$0=$ no relevance $/ 4=$ high relevance \\
$0=$ no relevance $/ 4=$ high relevance \\
$0=$ no relevance $/ 4=$ high relevance \\
\end{tabular} \\
\hline $\begin{array}{l}4.2 \text { Marketing } \\
\text { (Hansen } \text { et al., 2013; } \\
\text { O’Cass and Weerawardena, 2010) }\end{array}$ & $\begin{array}{l}\text { Product } \\
\text { The pricing of the main product } \\
\text { Sophistication of distribution channels } \\
\text { Applied marketing and communication tools } \\
\text { Marketing innovation }\end{array}$ & $\begin{array}{l}0=\text { no relevance } / 4=\text { high relevance } \\
0=\text { no relevance } / 4=\text { high relevance } \\
0=\text { no relevance } / 4=\text { high relevance } \\
0=\text { no relevance } / 4=\text { high relevance } \\
0=\text { no relevance } / 4=\text { high relevance }\end{array}$ \\
\hline $\begin{array}{l}4.3 \text { On line presence } \\
\text { (Aral and Weill, 2007; } \\
\text { Tippins and Sohi, 2003) }\end{array}$ & $\begin{array}{l}\text { Webpage technical characteristics } \\
\text { Webpage offered services } \\
\text { Webpage content } \\
\text { Online marketing applications }\end{array}$ & $\begin{array}{l}0=\text { no relevance } / 4=\text { high relevance } \\
0=\text { no relevance } / 4=\text { high relevance } \\
0=\text { no relevance } / 4=\text { high relevance } \\
0=\text { no relevance } / 4=\text { high relevance }\end{array}$ \\
\hline $\begin{array}{l}\text { 4.4 Decision making } \\
\text { (Györi et al., 2019; } \\
\text { Lafuente, Szerb et al., 2020) }\end{array}$ & $\begin{array}{l}\text { The application of the different sources of information } \\
\text { The application of financial analyses in the business Information sharing } \\
\text { Consultation in decision making } \\
\text { Administrative routines/operations knowledge sharing of the business } \\
\text { organization }\end{array}$ & $\begin{array}{l}0=\text { no relevance } / 4=\text { high relevance } \\
0=\text { no relevance } / 4=\text { high relevance } \\
0=\text { no relevance } / 4=\text { high relevance } \\
0=\text { no relevance } / 4=\text { high relevance }\end{array}$ \\
\hline $\begin{array}{l}\text { 4.5 Competitive strategy } \\
\text { (Bayon and Aguilera, 2020; } \\
\text { Sirmon et al., 2010) }\end{array}$ & $\begin{array}{l}\text { The direction of strategy (defensive, proactive) } \\
\text { Growth strategy based on the number of business units } \\
\text { The leader's entrepreneurial traits } \\
\text { The uniqueness of firm' proactive strategy. }\end{array}$ & $\begin{array}{l}\text { Numerical value } \text { (NACE codes) } \\
0=\text { no relevance } / 4=\text { high relevance } \\
0=\text { no relevance } / 4=\text { high relevance } \\
0=\text { no relevance } / 4=\text { high relevance }\end{array}$ \\
\hline
\end{tabular}

Note: The data was collected from the Global Competitiveness Project databases (GCP: www.sme-gcp.org). Details on the data collection process are presented in Section 4.1. Source: The business competitiveness index follows the methodology proposed by Lafuente, Leiva et al. (2020). 
Appendix 4. Data Envelopment Analysis (DEA): A brief description

Efficiency literature dealing with multiple inputs generating multiple outputs usually employs Data Envelopment Analysis (hereafter DEA) frontier methods (see, e.g., Cook et al., 2014). DEA is a non-parametric technique that, through linear programming, approximates the true but unknown technology without imposing any restriction on the sample distribution. The primary technological assumption of DEA is that any production unit (in our case, firm) (i) uses $\mathbf{x}=\left(x_{1}, \ldots, x_{j}\right) \in R_{+}^{J}$ inputs to produce $\mathbf{y}=\left(y_{1}, \ldots, y_{m}\right) \in R_{+}^{M}$ outputs, and these sets form the technology $(T): \mathrm{T}=$ $\{(\mathbf{x}, \mathbf{y}): \mathbf{x}$ can produce $\mathbf{y}\}$.

DEA is a complex benchmarking technique that yields a production possibilities set where efficient decision-making units positioned on this surface shape the frontier. For the rest of units DEA computes an inefficiency score indicating the units' distance to the best practice frontier.

The technology in DEA models has two properties that are worth defining. The first property relates to the returns to scale. The modeled technology may exhibit constant returns to scale (CRS) - more linked to long-term efficiency or to the modeling of composite indicators using the 'Benefit of the Doubt' approach used in this study — or variable returns to scale (VRS) connected to pure technical efficiency measures that capture outcomes linked to practices undergone in the short term (Chambers and Pope, 1996). The second assumption deals with the measurement orientation (input minimization or output maximization). The decision on the orientation approach relies on whether the technology of the analyzed units is more oriented to produce output targets with minimum inputs or to the production of the maximal possible output given the resources available (Cook et al., 2014; Grifell-Tatjé and Lovell, 2015).

For illustrative purposes, the following linear program models a DEA technology—assuming VRS and an output orientation—and computes the efficiency scores for a set of units (i): $D\left(\mathbf{x}, \mathbf{y}^{t}\right)=$ inf: $(\theta>0:(\mathbf{x}, \mathbf{y} / \theta) \in T)$, where $T$ is the technology:

$\mathrm{T}(\mathbf{x}, \mathbf{y})=\sum_{i=1}^{N} \lambda_{i} \mathbf{y}_{i, m} \leq \theta_{i} \mathbf{y}_{i, m} ; \sum_{i=1}^{N} \lambda_{i} \mathbf{x}_{i, j} \leq \mathbf{x}_{i, j} ; \sum_{i=1}^{N} \lambda_{\mathrm{i}}=1 ; \lambda_{i}>0$

The drawn technology in equation (A1) describes how units transform their available resources (x) into the maximum possible output (y), uses $\lambda$ as intensity weights to form the linear combinations of the sampled units $(i=1, \ldots, N)$, and introduces the restriction $\sum_{i=1}^{N} \lambda_{i}=1$ to impose variable returns to scale (VRS) to the technology. The term $\theta_{i}$ is the efficiency score obtained for each unit, and for efficient units $\theta_{i}=1$, whereas for inefficient units $\theta_{i}>1$ and $\theta_{i}-1$ points to the 
degree of inefficiency. To ease the interpretation of DEA results, Figure A1 presents a simplified representation of the output-oriented distance function. In the figure, suppose that a fictitious unit (E) has an inefficiency coefficient of $\theta=1.50$. Thus, to operate efficiently and reach the frontier $\left(E^{*}\right)$ this unit should expand its output by $50 \%$, while keeping its inputs fixed.

Figure A1. Efficiency analysis based on DEA models (VRS and output orientation)

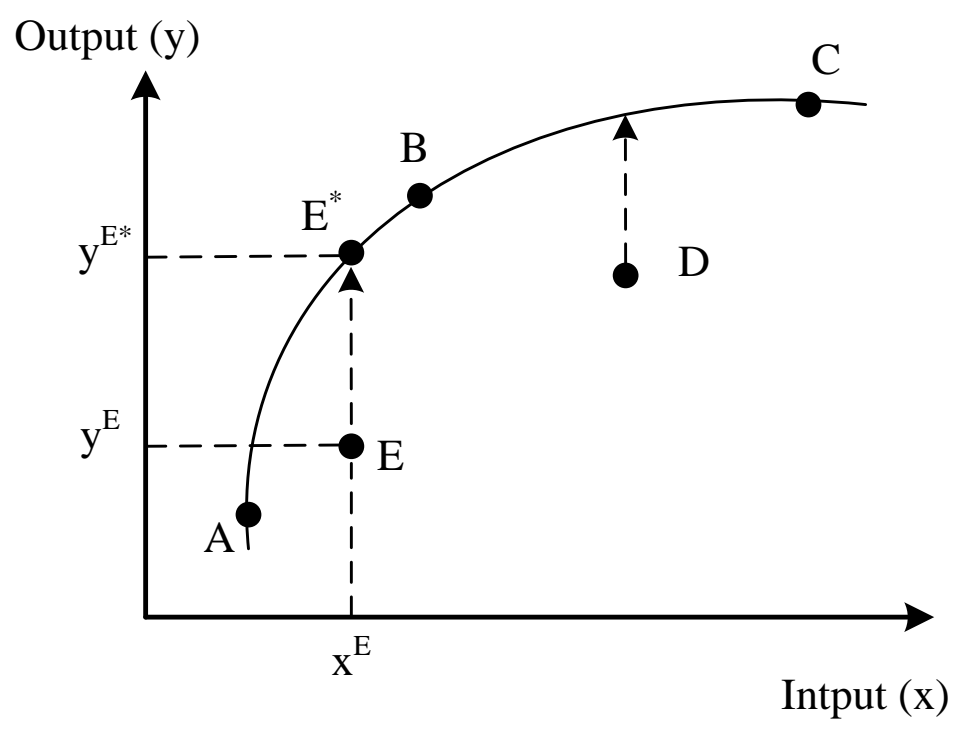

Source: Authors’ elaboration. 
Appendix 5. Reliability test: Summary results for the output set used in the BOD model

\begin{tabular}{|c|c|c|c|c|c|}
\hline & \multicolumn{5}{|c|}{ Index number and outputs used to compute the BOD model } \\
\hline & $\begin{array}{l}\text { Competitiveness } \\
\text { index }\end{array}$ & $\begin{array}{l}\text { y1: Human } \\
\text { capital }\end{array}$ & y2: Markets & y3: Innovation & y4: Strategy \\
\hline No. variables & 10 & 1 & 2 & 2 & 5 \\
\hline \multicolumn{6}{|l|}{ Panel A: France } \\
\hline Cronbach’s alpha & 0.9608 & ----- & 0.8647 & 0.9449 & 0.8935 \\
\hline \% variance explained & 0.7504 & ----- & 0.8808 & 0.9478 & 0.7108 \\
\hline \multicolumn{6}{|l|}{ Panel B: Spain } \\
\hline Cronbach’s alpha & 0.8507 & ----- & 0.7148 & 0.7843 & 0.7453 \\
\hline \% variance explained & 0.5886 & ----- & 0.5656 & 0.8493 & 0.5611 \\
\hline \multicolumn{6}{|l|}{ Panel C: Costa Rica } \\
\hline Cronbach’s alpha & 0.8271 & $\begin{array}{ll}---- \\
\end{array}$ & 0.7150 & 0.7561 & 0.7176 \\
\hline \% variance explained & 0.5054 & ----- & 0.5304 & 0.7328 & 0.5250 \\
\hline \multicolumn{6}{|l|}{ Panel D: Hungary } \\
\hline Cronbach’s alpha & 0.9115 & ----- & 0.7688 & 0.7858 & 0.8264 \\
\hline \% variance explained & 0.6193 & $\begin{array}{ll}---- \\
\end{array}$ & 0.8122 & 0.8236 & 0.6133 \\
\hline
\end{tabular}

Note: The Competitiveness index includes the 10 variables described in Appendix 3: human capital, domestic market, internationalization, product innovation, technology, networks, online presence, marketing, decision making, and competitive strategy. The variables included in the outputs are the following: Human capital output (y1): human capital; Markets (y2): domestic market and internationalization; Innovation (y3): product innovation and technology; Strategy (y4): networks, online presence, marketing, decision making, and competitive strategy. 
Appendix 6. Kolmogorov-Smirnov test of equality of distributions: Summary results

\begin{tabular}{|c|c|c|c|c|}
\hline & France & Spain & Costa Rica & Hungary \\
\hline \multicolumn{5}{|c|}{ Panel A: Full sample } \\
\hline France & $\begin{array}{c}-- \\
-\end{array}$ & $0.2751^{* * *}$ & $0.2059 * *$ & $0.2297 * * *$ \\
\hline Spain & & --- & $0.2614 * * *$ & $0.2694 * * *$ \\
\hline Costa Rica & & & --- & 0.1687 \\
\hline Hungary & & & & --- \\
\hline \multicolumn{5}{|c|}{$\begin{array}{l}\text { Panel B: } \\
\text { Manufacturing firms }\end{array}$} \\
\hline France & --- & $0.3139 * * *$ & $0.3031^{* *}$ & 0.1954 \\
\hline Spain & & --- & 0.1403 & $0.2773 * *$ \\
\hline Costa Rica & & & --- & 0.2313 \\
\hline Hungary & & & & --- \\
\hline \multicolumn{5}{|c|}{ Panel C: KIBS firms } \\
\hline France & --- & $0.3667 * *$ & $0.4792 * * *$ & $0.3833 * *$ \\
\hline Spain & & --- & $0.4501 * * *$ & $0.2938^{*}$ \\
\hline Costa Rica & & & --- & $0.2913 *$ \\
\hline Hungary & & & & --- \\
\hline
\end{tabular}

*, **, *** indicate significance at the $10 \%, 5 \%$ and $1 \%$, respectively. 
Appendix 7. Distribution function (Kernel) of BOD scores for the analyzed countries

The non-parametric Kernel density method—originally proposed by Rosenblatt (1956) and Parzen (1962)—computes the underlying probability density function (pdf) of a random continuous variable $(\mathrm{X})$ under smoothness assumptions. That is, the Kernel density estimator shows how the probability mass of the sampled data $(\mathrm{N})$ is distributed over the values of $\mathrm{X}$ (X-axis) (Asta, 2021).

The Kernel density estimator is generally defined as: $f_{\left(x_{1}, \ldots, x_{N}\right)}^{h}(x)=\frac{1}{N h} \sum_{i=1}^{\mathrm{N}} K\left(\frac{x-\mathrm{X}_{\mathrm{i}}}{h}\right)$, where $K$ is a Kernel function used to estimate the density $(f)$ based on the observed data $\left(\mathrm{X}_{i}, \ldots, \mathrm{X}_{\mathrm{N}}\right)$, and $h=h_{N}>0$ is the sequence of smoothing parameters or bandwidths. In this study, the symmetric Epanechnikov is the Kernel function ( $f$ ) used to compute the density estimates. Notice that for symmetrical kernel functions the choice of the shape of the function $(K)$ has a rather insignificant effect on estimations (Silverman, 1986). By using the specific location of observed data points, the resulting Kernel density plot reveals more accurately the true concentration of the sampled data, which helps to better interpret the information contained in the sample.

In the context of our study, the density plots show if BOD scores are more concentrated in lowefficiency areas (values close to 0) or in mid- and high-efficiency areas (values close to 1). For interpretation purposes, these results complement the findings of standard descriptive statistics.

Figure A2. Kernel distributions: BOD results for France

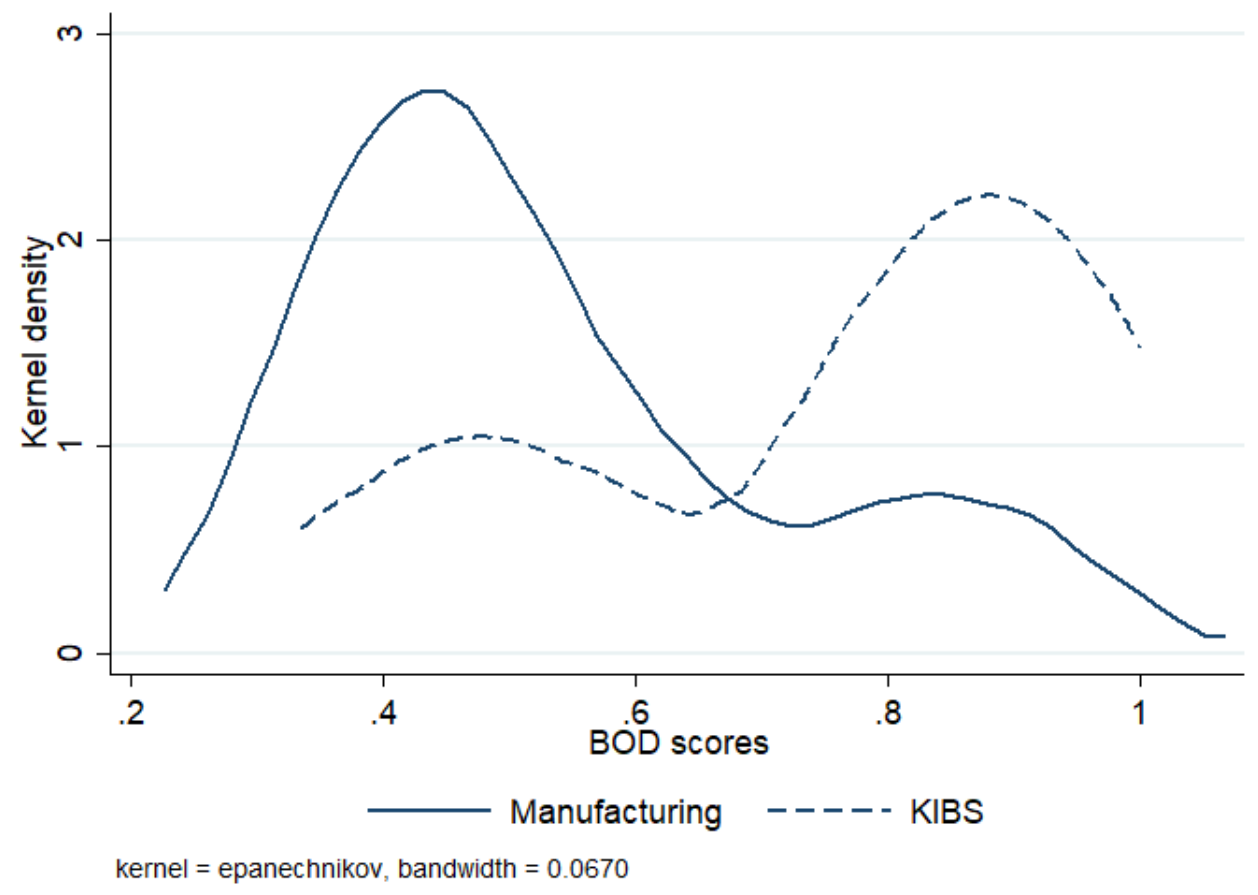


Figure A3. Kernel distributions: BOD results for Spain

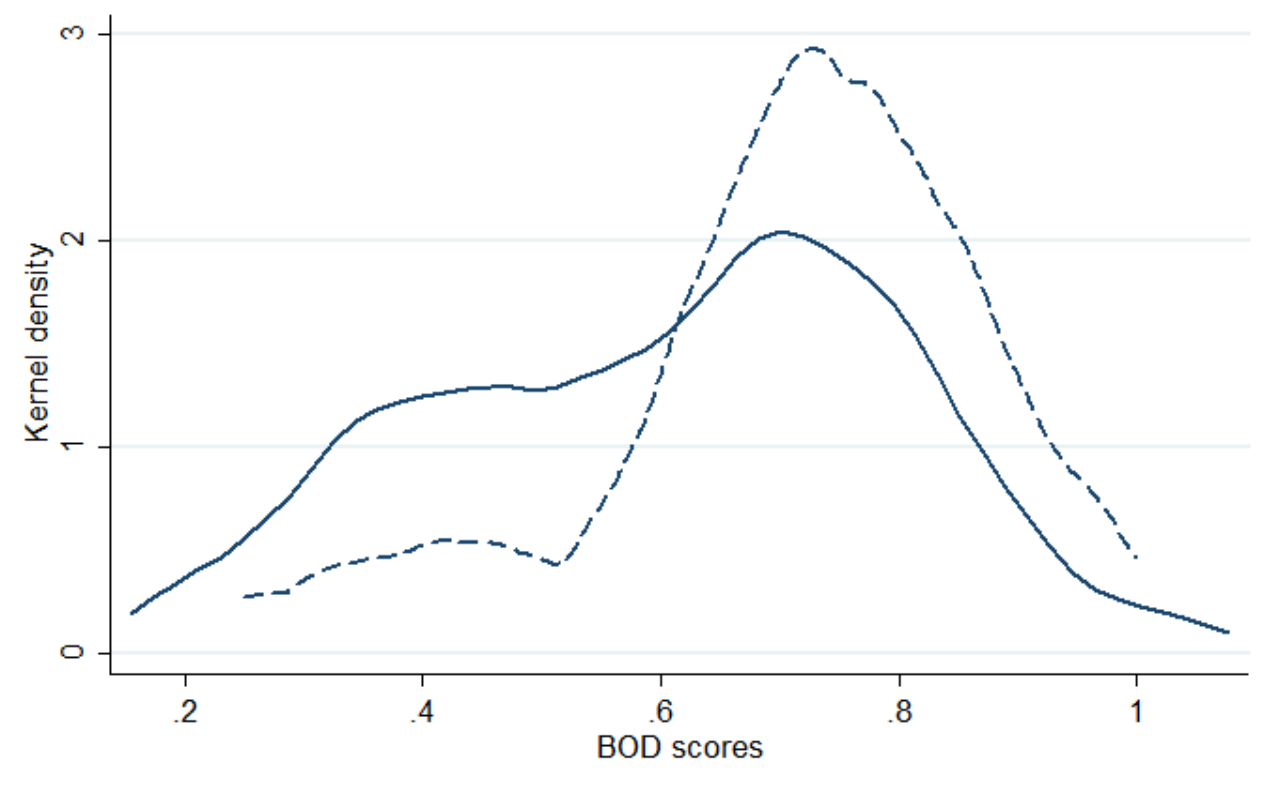

Manufacturing firms $\quad-----$ KIBS firms

kernel $=$ epanechnikov, bandwidth $=0.0772$

Figure A4. Kernel distributions: BOD results for Hungary

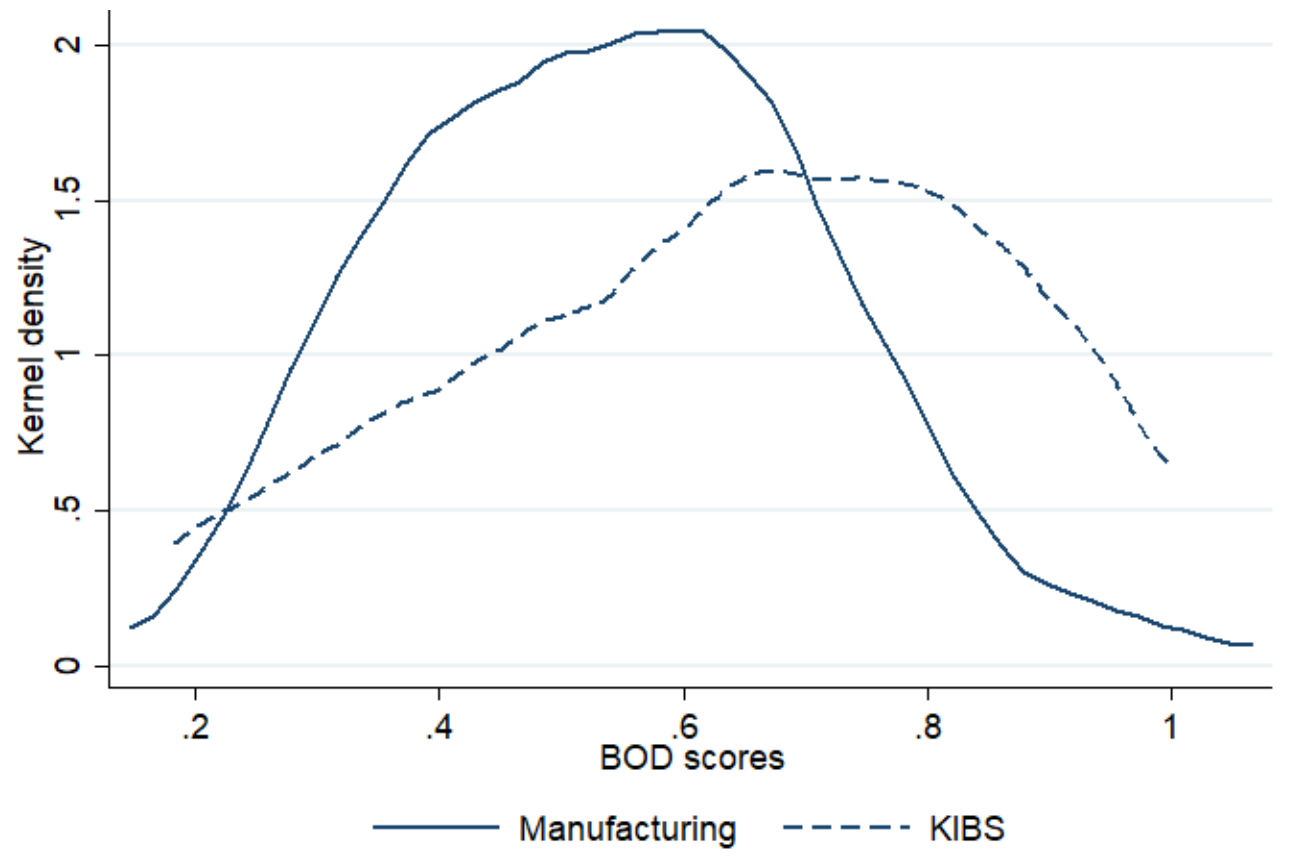

kernel $=$ epanechnikov, bandwidth $=0.0660$ 
Figure A5. Kernel distributions: BOD results for Costa Rica

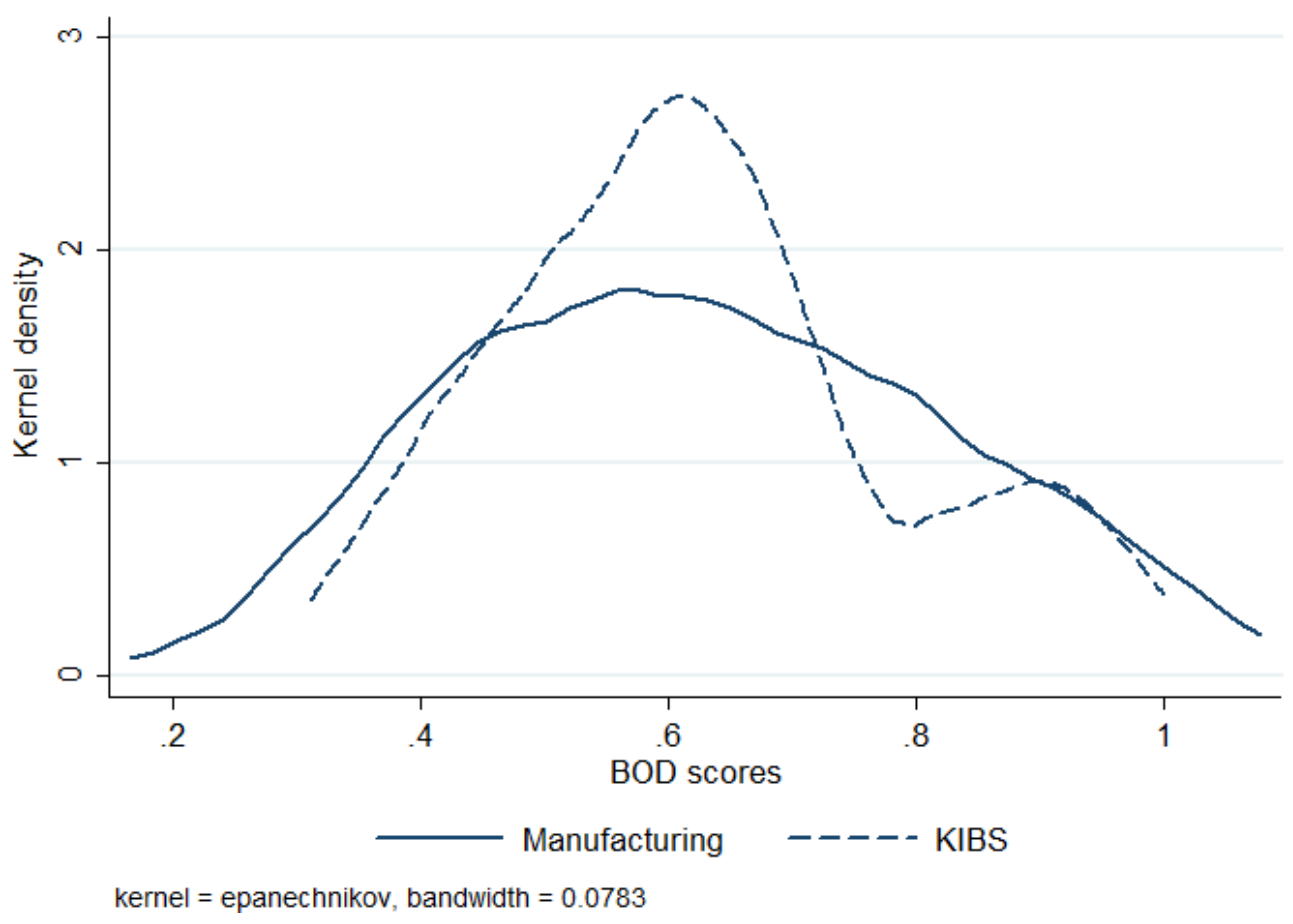

